\title{
Tax Avoidance and the European Court of Justice: What is at Stake for European General Anti-Avoidance Rules?
}

\author{
Professor Violeta Ruiz Almendral, ${ }^{1}$ Tax and Finance Law, Universidad Carlos III de Madrid
}

Tax shelter: 'a deal done by very smart people that, absent tax considerations, would be very stupid' $(\text { Michael Graetz) })^{2}$

\section{1. introduction}

Spain has recently introduced a new general antiavoídance rule $^{3}$ (GAAR) that presents many similarities with other existing GAARs and anti-avoidance judicial doctrines. But these are harsh times for such rules. While on the one hand the present context of growing globalisation offers an ever greater panoply of opportunities for tax planning, on the other, many anti-avoidance measures have been the target of certain decisions by the ECJ, on the grounds that they put the correct functioning of the EC fundamental freedoms in jeopardy. It is then pertinent to reflect upon the meaning of GAARs, taking into account the European context, and especially the ECJ case law on this matter, which apart from having a growing incidence in the desígn of the taxes in the EU, is increasingly penetrating the core of the definition of tax avoidance.

Implementing any measure that limits the possibilities of tax planning in any way, especially if it is a GAAR, is usually welcomed with much discussion. Passion is not unknown to the Spanish character, and the reform has been received with a mixture of serious tax debate and misconceptions about what exactly the role of taxes should be. Interestingly, the terms of the discussion do not greatly differ from the debate that has taken place in other countries. ${ }^{4}$ This is hardly surprising, as there is a high level of coincidence among most existing GAARs. As I will later show, the Spanish GAAR shares many features with the Germán rule (s. 42.1 Ahgabenordnung (AO)), but does not greatly differ, in its core, from the Australian or the Canadian rules, or for that matter, from the main lines of tax avoidance case law in the US, Canadá, Australia or the UK.

Technically though, the new Spanish GAAR is really not that new. There have been other GAARs in the past, since the enaetment of the General Tax Code of 1963 (Ley General Tributaria (LGT)). The 'added valué of this new provisión is to try and revitalise its use by the tax administration and the courts, by defining avoidance in a much clearer manner, thus serving as a more reliable guideline for the recharacterization of arrangements that fall within its scope.

In this article I will first convey the'general aspeets of a GAAR and anti-avoidance doctrines, connecting their main features with the new Spanish provisión, and secondly, $\mathrm{T}$ will assess the pertinent ECJ decisions and how they may affect its understanding and its use in the European context. Finally, I will. pay special attention to a recent Opinión of Advócate General Mr. Poiares Maduro, that implies a certain change in the tradicional ECJ doctrine.

\section{Notes}

The author would like to chank Proíessor J M Calderón Cañero (Universidad de La Coruña) for his valuable comments on the fírst manuscript, which have considerably improved the fina) text Needlcss to say, the author rcmains accountable for all remaining errors

As quoted by Tom Hermán, Tax Rcport, Wall Street Journal, 10 February 1999, p A-1

Section 15 of the Ley 58/2003, General Tributaria, the General Tax Code that replaces the previous one, containcd in Ley 230/1963, General Tributaria

Compare the eritic of Brian Arnold, 'The Canadian Anti-Avoidanee Rule', British Tax Review 1995, no 6, pp 549, 553 and 554 (including footnotes ns 31,41 and 46), to Colin Masters, is There a Need for General Anti-Avoidance Legislación in the United Kingdom?', British Tax Review 1994, no 6, who is contrary to the introduction of a GAAR, with the critics of Palao, 'Economía y Derecho en la aplicación de las leyes tributarias" Crónica Tributaria 1995, no 73; 'Existe el fraude a la ley tributaria?', Revista Estudios Financieros 1998, no 182; 'La norma anti-elusión del proyecto de nueva ley general tributaria', Revista Estudios Financieros 2003, no 66 to the opinions of FALCON and Telia, 'El fraude a la Ley tributaria como un mecanismo para gravar determinadas economías de opción (I): su radical diferencia con los supuestos previstos en el are 6 C C, Quincena Fiscal 1995, no 17; 'Fl fraude a la Ley tributaria como un mecanismo para gravar determinadas economías de opción (II): limites a la utilización de esta figura', Quincena Fiscal 1995, no 18 and Juan José Lapatza Ferreiro, 'Economía de opción, fraude de ley, sancios y delito fical', Quicena Fiscal 2001, no 8, who a', Qunce sancios y delio fist. Quincena Fiscel 2001 , no 8 , who a different as the Spanish and the Canadian tax systcms may be See similar arguments in the rcactions to the UK GAAR proposal put forward by the IFS, Tax Avoidance: A repon by the Tax Law Review Committee (IFS, 1997), at Graerne Cooper, 'International experience with general anti-avoidance rules', Southern Metbodist University Law Review 2001, no 83 


\section{The common elements of most genera! anti avoidance rules}

There are a number of reasons why governments need to tackle tax avoidance. The main one is that it distorts the allocation of the tax burden among citizens. It is then regarded as one of the dangers affecting the soundness and coherence of the tax systems, in that such phenomena may end tip preven ti ng them from the fulfilment of their objectives, partly, because of its negative incidence on the main equalky principies (i.e. ability to pay, general taxation, etc.). In the end, as the Spanish Constitutional Court (TC) put it, it is a zerosum game, as 'what remains unpaid by those who should have paid it, will eventually have to be paid by other citizens that are either more law abiding or have less practical possibilities to avoid taxes'. ${ }^{5}$

The above considerations are common knowledge in the literature of tax avoidance but it is necessary to stress the point because anti-avoidance provisions, or anti-avoidance case law, when authentic, constitute a necessary complement to one of the pillars of a taxation system: its equality. Accordingly, it has often been understood that such provisions conform a constitutional requirement in order to protect the equality principies, to the extent that such principies are enshrined in the Constitutions. ${ }^{6}$

The measures designed to counter tax avoidance do not differ greatly. Be it in the form of a GAAR, or the consequence of anti-avoidance case law, there are a number of common elements that can be traced down in every group of measures, in all countries. This is consistent with a certa $\mathrm{i} n$ level of resemblance in all tax systems, at least in the way tax norms are designed. In short, most anti-avoidance measures are very similar, or at least come to very similar conclusions.

The differences among GAARs and case law doctrines lay not really in the elements themselves, for all of them are more or less common, but on the stress or importance given to one of them in detriment of the others. Thus, while in Germany special importance is given to the misuse or the abuse of the legal forms ${ }^{8}$ (Gestaltungsmibbrauch) that lead to a certain arrangement, in the US stress is laid on the absence of any valid economic reason (i.e. business purpose test) for the adoption of a given legal form or arrangement. As I will later show, here too lay the main differences between the ECJ concept of tax avoidance and the Member States'.

To the extent that it bestows certain importance on form, the Spanish norm may be traditionally closer to the Germán. However, it also encapsulates certain elements of the business purpose test doctrines. Section 15 of the LGT mainly refers to a problem of interpretation; in which the way the taxpayer has interpreted a certain provisión differs, 'confliets', with that intended by the purpose of the law. Such a conflict $^{9}$ will arise:

'when the taxpayer succeeds in total or partially avoiding the tax, or obtains a tax benefit of any kind through acts or arrangements in which both the following circumstances oceur: (a) Individually considered or, as a group such acts are clearly artificial or improper for attaining the pursued economic objective; (b) That no other substantial consequences arise from the adoption of this legal form or arrangement as would have arisen had the normal, proper form be used.'

The main reason why this norm has been changed lays in the disorderly, even erratic, manner in which Spanish tax authorities had been interpreting the previous tax avoidance provisión, together with the rest of the anti-avoidance measures, such as the antisham or simulation provisión or the adequate interpretation provisions. Two main reasons serve to explain the almost legendary reluctance to employ the provisión: one is that it expressly excluded the

Opinión no 76/1990, 26 Aprii (FJ 4) Scc thcsc arguments at: IFS, n 4 abovc, p 4; Juan María Barqero Estevan, La función del tríbulo en el Estado Social y Democrático de Derecho (Centro de Estudios Constitucionales, Madrid, 2002), p 81 This is already having a direct incidence in public expenditure, and in that way, in the welfare modeis of Member States; see in this regard, inter alia: Avi-Yonah, 'Globalisation, tax competition, and the fiscal crisis of the Welfare State', Harvard Law Review 2000, vol 113, no 7, p 1575; Miguel Ángel Caamaíio Anido and José Manuel Calderón Carrero: 'La erosión de las medidas de control fiscal del Estado de residencia: una reflexión al hilo de la jurisprudencia comunitaria en el caso JC/ Revista de Contabilidad y Tributación 2000, no 207, p, 245

Danzer, 1981, p 25; Kirchhof, 1983, p 175; Klaus Tiplee: Die Steuerrecbtsordnung, Verlag Dr Orto Schmidt, vol III, p 1330; Dieter Birk: Steuerrecbt I. Allgemeines Steuerrecbt, Verlag C H Beck (München, 1994), pp 106 and 107; Uwc Paschen (2001): Steuerumgebung im nationalen una internationalen Steuerrecbt, Verlag $\mathrm{GmbH}$ (Wiesbaden. Deutscher Universitáts, 2001), p $55 \mathrm{Scc}$ this idea in the Germán Constitutional Court (BverfG, hereafter) of 2 October 1968 - 1 BvF $3 /$ 65, BVerfGE 24,174, and the Spanish TC, vid. Opinions nos 76/1990, 46/2000 and 194/2000 See José Manuel Calderón Carrero (2000a): 'Aspectos internacionales del fraude y la evasión fiscal', at C García Novoa and A López Diaz: Temas de Derecho Penal Tributario (Marcial Pons, Madrid, 2000), p 204

Fernando García Prats: 'Las medidas tributarias anti-abuso y el Derecho Comunitario', at: Serrano Antón and Soler Roch: Las medidas anti-abuso en la normativa interna española y en los convenios para evitar la doble imposición internacional y su compatibilidad con el Derecho Comunitario (Instituto de Estudios Fiscales, Madrid, 2002), p 164 maintains a different view, on the grounds of the works of Avery Jones et al., 'The business purpose test and abuse of rights', British Tax Review 1985, no 2 and Coopcr, see n 4 above In my opinión, precisely those studies point to the opposite conclusión; that there are fundamental coincidenccs in all general anti-avoidance rules Avery Jones et al. pointed to the similarities, in the results, of anti-avoidance theories and provisions in continental and common law (p 76) Almost 20 years after that wotk, their similarities are specially intense, see in this regard: IFS, n 4 above; Cooper, n 4 above, pp 97-108; Violeta Ruiz Almendral and Georg Seitz: 'El fraude a la ley tributaria (análisis de la norma española con avuda de la experiencia alemana)' Revista Estudios Financieros 2004, pp $257-258$

Section 421 of the AO 'Tax law cannot be circumvented by the abuse of legal constructions In the case of an abuse, tax vvill be due as if a legal arrangement, which is adequate to the cconomie substance of the arrangement, had taken place': see Ruiz Almendral at $n$ des Art, 15 Ley General Tributaria (LGT) - Ist der deutsche s 42 AO ais Vorbild geeignet?', Steuer und Wirtschaft 2004, no 4

The term 'conflict', cmploycd for the first time by the LGT 2003, is somewhat deceptive, in that it may mislead the interpretation of the provisión, which is an antiavoidance provisión in its own right, not a mere description of a conflict; Palao Taboada, see n 4 above, p 73; Ruiz Almendral, see n 8 above, p 16 
possibility of sanctioning taxpayers incurring in it, the second is that the provision has always required tax authorities to rollow a special procedure in order to guarantee its correct and unified interpretation. In practice, tax authorities and the courts have circumvented the provisión and recharacterized certain arrangements by re-interpreting them in the light of the tax norms, or declaring the existence of sham. To a certain extent, this practice has constituted an avoidance of the tax avoidance provisión in its own right. ${ }^{10}$ The present provisión no longer requires tax authorities to follow a special process, although a consultative commission must decide whether or not the different elements of tax avoidance are present (s. 159). ${ }^{11}$ However, the new LGT makes it even harder to clifferentiate between avoidance and sham or simulanon, regulated in s. 16. This matters in Spain, for only in the latter cases may the tax authorities impose sanctions. In the author's view, the differences among sham and avoidance are not really ontological, as they share the same naturé, differing only in the degree of bluntness or sophistication that the avoidance transaction has been dressed up vvith. ${ }^{12}$

Of course different reasons may explain vvhy a GAAR is used or not. In the cases of Spain, the situation can be qualifíed as a failure of the provisión, which was systematically 'avoided' by the authorities. In ocher countries, an adequate interpretation of the tax norms mav make it unnecessary."

\section{A. The structure of tax avoidance: is there a 'right' to save taxes?}

According to the classical design of taxes, the burden usually t'alls on an economic reality that has previously been regulated, classified or characterised by other branches of law (commerce or other prívate law). Because citizens are free to choose anv lesa] form among a panoply of options, they are indirectly bound to have an influence upon their final tax debt, or on whether or not the debt will actually arise. ${ }^{14}$ Therefore, there is no such thing as a right to avoid or minimise taxes. The possibility of diminishing the tax burden by employing a certain legal form instead of another is a mere natural consequence of the common structure of taxes as we know them. Moreover, as U. Paschen put it, the (famous) statement that 'every taxpayer is entitled to arrange his affairs in order to pay the minimal possible tax' is only strict truth for those cases where the tax norm expressly establishes an incentive/ disincentive. For the normal tax burden, that statement would be the exception. ${ }^{15}$ In short, legitímate tax micigation or tax planning [economía de opción, Steuerverrneidung) is nothing more than a side effect or an iridirect consequence from the exercise of the free will in a market economy.

That avoiding taxes is not a right may seem quite obvious at first sight. If taxes are a democratically agreed collective contribution to the financing of public expenditures, why then should there be a right ro avoid them? However, this conclusión has often been jumped to when analysing the core structure of taxes. The most quoted example of such idea can be found in Duke of Westminster, which constitutes a good example of the so-called 'pro-taxpayer líteralism', ${ }^{16}$ which has also had a decisive influence outside the UK. For example, it was this line of thought that virtually deprived the Australian GAAR of 1936 of any effectiveness, which led to its reform in $1981,{ }^{17}$ as well as the reform of the Acts Interpretation Act in order to enhance the use of purposive interpretation by the courts, thus making up for the said literalism. ${ }^{18}$ And this is not just a matter of terminology. When what is only a natural consequence of taxation is turned into a 'right', thus missing the nuances, taxpayers feel entitled to pursue it - as they would pursue any other right - and

\section{Nates}

10 Palao, sec n 4 above

11 See Ruiz Almendral and Seitz, n 7 above Whether or not that process is accually necessary, is not quite clear; see Jesús López Tello(2003): 'La "cláusula antiabuso" del anteproyecto de la nueva ley general tributaria', Actualidad jurídica Una \& Menéndez 2003, no 5, p 53

12 Most Spanish scholars do not share this view, and maintain the existence of a difference; Ínter alia: Juan Zornoza Pérez: 'La simulación en Derecho Tributario', Boletín del Ilustre Colegio de Abogados de Madrid 2000, no 16

3. See the Canadian case, where to the moment fcw cases have rnade it to the courts; Arnold, see $\mathrm{n} 4$ and also 'The Canadian General Anti-Avoidance Rule', in Graeme S Cooper (ed ): Tax Avoidance and the Rule of Law (International Bureau of Fiscal Documentación, Amsterdam, 1997); IFS, see n 4, p 23

if Rainer W Walz: Steuergerechtigkeit und Rechisanivendung. Gntndlinien einer reiativ autonomen Steuerrechtsdogmatik (Decker, Heidelberg, 1980), p 227; Danzer, 1981, p 105; Tiplee, n 6 above, pp 1329 and 1330; Paschen, n, 6 above, pp 41 and 42

Paschen, see n 6 above, p 103

is Comrnissioners of Inland Revenue $\mathrm{v}$ Duke of Westminster [1936] App Cas 1 Karsten Nevermann: Justiz und Steuerumgehung (Ein kritischer Vergleich de Haltung der Dritten Gewalt zu kreativer steuerlicher Gestaltung in GroKbritannien und Deutschland) (Duncker \& Humblot, Berlin, 1994), p 298 See a strong and somewhat grotesque defense of such literal pro-taxpayer interpretación at Lord Houghton of Souwerby: Tax Avoision. The Fuliliy of Taxation by Menaces (1979), p 93. See abundant examples, and a critic, of this view of tax avoidance as a sort of right at: Cooper, $\mathrm{n} 4$ above, $\mathrm{p} 86$

7. The Income Tax Assesrnent Act 1936 was subject to a reform; scc in detail: John Passant: 'Tax Avoidance in Australia: The Return of the Ghost?', Britisb Tax Review 1996, no 4, p 453; Frans Vanisrendael: 'Judicial interpretation and the role of anti-abuse provisions in Tax Law', Graeme S Cooper (ed ): Tax Avoidance and the Rule of Law. Amsterdam: International Burean of Fiscal Documentation, Amsterdam, 1997), pp. 141-142

is Accs Interpretation Act 1901, s 15AA(1), which states: 'In the interpretation of a provisión of an Act, a construcción that would promote the purpose or object underlying the Act (whether that purpose or object is expressly stated in the Act or not) shall be preferred to a construcción that would not promote that purpose or object' 
aggrcssive tax planning ensues. ${ }^{19}$ It is then forgotten that 'The legal right of a taxpayer to decrease the amount of what otherwise would be his taxes, or altogether avoid them' is only possible when undertaken 'by means which the law permits'. ${ }^{20}$ In the end, to name what is nothing more than the natural consequence - a decrease in the tax debt - of an option - to choose one legal form or another - a right, departs from an 'underlying assumption... that the tax laws are confiscations of prívate property, interferences with the natural order of the free market, and violations of civil liberty...' what constitutes, 'a nineteenth century relie' ${ }^{21}$

What qualifies a certain arrangement as tax avoidance is the abuse, the misinterpretation or the manipulation of those legal forms, to the extent that they are taken into account by the tax norrns. Henee, while legitimare tax planning is not against the purpose of the tax laws, tax avoidance complies only literally with such laws, albeit not in spirit. ${ }^{22}$ There are three basic elements in every avoidance arrangement: the legal means, form or arrangement employed to attain a given objective is not adequate justification; the only reason such an arrangement was entered into at all was to reduce taxes and there is no other substantial reason (safe harbour rules) or valid motive to justify its employment. These three elements are closely related, and must always be present at the same time. For the sake of clarity, I will treat them in a sepárate manner, as artificial as such a treatment may be, for in the logical argumentation process the interpreter should deal with all three elements in a circular manner.

\section{B. Testing the form: an artificias, strange, inadequate or contrived legal form or arrangement}

Section 15.1 of the LGT refers to acts or arrangements that are 'clearly artificial or improper for attaining the pursued economic objective' as opposed to some '(h) proper form' that could have been used. This is common to many GAARs, precisely because taxes derive from the use of a number of legal forms (arrangements, contraets, businesses), stress is put on the form itself. ${ }^{23}$ Should this be inappropriate to the means and objectives, there will be some hint or indication of $\operatorname{tax}$ avoidance. Actually, the most common form of tax avoidance will derive from an abuse of the freedom of forms for the purpose of tax mitigation.

As clear as this may be in the theory, the question remains of exactly what can be considered inappropriate, which leads to the question: in comparison with what should this form be considered inadequate. Merely stating that it is artificial, strange or unusual does not add much information, as these are all relative concepts. That could be, at the most, a primary or possible evidence of avoidance. ${ }^{24}$ Another criterion can be the 'third rational person' (Verstándiger Dritte), which is equivalent to saying that the form does not make much sense by itself, unless vve connect it with the obtaining of a tax benefit. This way of arguing requires the establishment of an ideal standard which serves as a comparison point, in order to establish a relationship between the economic objective and the legal means. ${ }^{25}$ In this regard, the term 'artificiar, meaning a lack of logical and coherent correspondence of the arrangement and the underlying economic reality is more precise, and is most used by GAARs (such as the Australian, '... blatant, artificial or contrived arrangements $\left.\ldots{ }^{\prime}\right) .^{26}$

Whatever criterion we decide to choose, it is most important to bear in mind that the comparison perspective must always reside in the tax norm or provisión. What should be the main object of examination is not so much whether or not the legal form is logically adequate to the economic objective that is being seeked, as much as this can be taken into account as a possible evidence, but whether or not such an arrangement or legal form is in accordance with the tax provisión itself. The purpose and significance of the tax measures must be the main element of comparison. The act or arrangement must be analysed as defined,

\footnotetext{
Notes

Many examples serve to prove this point; following the Stubart case (Stnbart Investments Ltd $v$ The Queen [1984] C T C 294), Reverme Canadá decided to publish a declaración of rights for the raxpayers, including the 'right to arrange your affairs in order to pay the minimum tax required by law' This stacement, followed by a strong tendency of litoral interpretación of tax stacutes led to a grcat increase to all sores of tax avoidance arrangements or aggressive tax planning, vvhich actually brought about a decrease of the revenues obtained by the corporation income tax between 1985 and 1987 This gave place to the final enaetment of the ('anadian GAAR; (s 245 of the Income Tax Acr (Statues Canadá 1970, chapter 63) See more details in Arnold, n 4 above, pp 543 and 549 and Arnold again at n 13 above, p 230 Something very similar happened in Belgium, that also enacted a GAAR (by an Act of 22 July 1993); see Luc Hinnekens: 'Uncertainties in the Interpretador! of the General Anti-Avoidance Statute', European Taxation, September 1999, p 339

$2 \pi$ Gregory v Heivering, 293 US 465 (1935)

P Hogg and J E Magce: Principies of ('anadian Income Tax IJIIV (Carswell, Toronto, 1996), p 447; Ruiz Almendral and Seitz, see $\mathrm{n} 7$ above

Hensel, 1923, p 244; Tipke, see n 6 above, p 1325; Birle, see n 6 above, p 106; IFS, see n 4 ahove, p ix; Palao Taboada, see n 4 above, p 79; Abelardo Delgado Pacheco: Las Normas Antiehtsián en la Jurisprudencia Tributaria española (Thomson-Aranzadi, Pamplona, 2004), p 43

IFS: see n 4 above, p 21 and pp 56-57

24 Henee the confusión in Germany thac has derived from certain line of case law that identified, in a more or less direct way, the term 'inappropriate' (unattgemessen) with '«inusual' (unüblicb/ungewóhnlich); see in this regard: Petcr Fischer: 'Dio Umgehung des Steuergesetzes', Der Betrieb, 29 March 1996, p 647; Paschen, see n 6 above, p 15

(Verstandige Dritte) This criterion is employed, Ínter alia, in: BFH 27 July 1999, BStBl 11 1999, 769

26 Passant, see n 17 above, pp 453 and 454; IFS, see n 4 above, pp 38 and 39; G T Pagone: 'Anti-Avoidance Provisions and Tax Reform', Australia» Tax Reivew 2001, p 81
} 
considered or taken into account by the tax provisión. The coherence must be looked for inside the tax norms, not outside. Such reference point is made clear in the Cañadian GAAR, which prohibits the 'misuse of the provisions of this Act or an abuse having regard to the provisions of this Act, other than this section, read as a vvhoie'. ${ }^{2}$ The Spanish and Germán rules do not expressly say anything, but that has also been the prevailing interpretation among commentators. ${ }^{28}$

In this analysis it is necessary to take into account the purpose of the tax norm and, specifically, whether or not that norm provides an incentive for that arrangement. Thus, once we know exactly what the purpose of the tax norm that has been avoided - or of the tax norm establishing a benefit that has been strived for - the following questions remain: whether or not the tax provisión has influenced the behaviour of the taxpayers and, specifically, whether that influence is consistent vvith the objectives and purposes of the Act.

This of course means that it will be essential to determine whether the tax provision intends to be neutral or not, with regard to that specific arrangement (for 'chemically puré" taxes do not really exist). As a general departíng point, where there is a neutral tax provisión, a tax-influenced behaviour stands a good chance of being an avoidance (tax driven) transaction. On the contrary, if the tax norm is dírectly neutral, the exam must focus on whether or not the act or arrangement complies with what that provision intended to encourage/discourage. It is then easy to see how neutrality in tax systems constitutes a breeding ground for the proliferation of tax avoidance. ${ }^{29}$

\section{Testing the substance; no other valia economic reason or the business parpóse test}

Once there is an artificial form leading to a tax benefit, it must he analysed whether there were other teasons for its adoption. Of course if there were, then maybe the form is not actually artificial after all, which shows how the analysis must be circular. Section 15 of the LGT expressly refers to the use of a legal form from which derive 'no other substantial consequences' leaving aside the tax benefit strived for. This provisión is a form of business purpose test. ${ }^{30}$ The idea is to deny legal protection - i.e. granting a tax benefit - to those transactions or arrangements deprived of any economic purpose which have (maybe precisely as a consequence of not having any business purpose, maybe not) abused the norms of public law (tax law) and of prívate law in the sense of using them only for the purpose of obtaíning a tax benefit, as the purpose of privare law is not to guarantee tax benefits but to facilítate economic transactions.

Thus, valid economic reasons is both a criterion to determine whether or not the form is artificial, or once concluded the form is maybe not artificial but contrived, etc., a way to save it from incurring in tax avoidance.

But s. 15 of the LGT goes further than merely determining a business purpose in the transaction. The idea is to find out whether or not the form complies with the purpose of the tax norm. A transaction may be perfectly sound in these terms and still be an avoidance transaction. It is important to take this element into account, for the obtaining of a tax benefit may be by itself a perfectly sound commercial objective. Sometimes it is easy to miss this nuance, and accept arrangements entered into for the solé purpose of avoiding taxes, arguing that the tax benefits were also a part of the objective of the business, and that it is only normal to want to minimise costs, and among these costs, those derived from taxes. An example of this reasoning can be found in the Spodess case, as resolved by the Australian Federal Court. The reasoning was corrected afterwards by the Supreme Court, in the sense defended here, by stating that:

'a particular course of action may be.. .both "tax driven and bear the character of a rational commercial decisión. The presence of the latter characteristic does not determine the answer to the question whether, within the meaning of Part IV.a [which is the Australian GAAR], a person entered into or carried out a "transaction" for the "dominant purpose" of enabling the tax payer to obtain a "tax benefit". 31

This last Court places particular emphasis on the fact that there is no necessary or logical dichotomy among an arrangement carried out for tax reasons or tax driven and rational commercial decisions, so the measuring standard must preferentially lie in analysing whether the operation does make sense or can be understood if we forget about the tax benefits. If we elimínate the tax benefit, the arrangement would not have been reasonable. It then naturally follows that its objective was purely to obtain a tax benefit. If that tax

\section{Notes}

The Canadian GAAR is contained in s 245 of the income Tax Act ( RSC 1985, c 1 (5th Supp))

27 Fischer, see n 24 above, p 648 ; Paschen, see n 6 above, p 93; Uwe Clausen: 'Struktur und Rechtsfolgen des $\$ 42$ AO', Der Betrieb, 25 July 2003 , pp 1591 and 1592; in Spain this idea was stressed in the special repon prior to the reform of the tax code: Informe LGT: 2001, p 44 In the samescnsc, see: López Tello, scc n II above, p 50

2 Paschen, see $\mathrm{n} 6$ above, pp 47,48 and 57

30 Palao: 'Los "motivos económicos válidos" en el régimen fiscal de las reorganizaciones empresariales', Revista Estudios Financieros 2002, no 2, p 81; López Tello, see $\mathrm{n} 11$ above, pp 51 and 52; Ruiz Almendral and Seitz, see $\mathrm{n} 7$ above

It FCT $v$ Spotless Services Ltd (19S5| (Federal Court), see more references and a critic at Passant, n 16 above, p 453 The second pan of the case took place at the Australian Supreme Court FCT $v$ Spotless 95 A T C 4775; see: Passant, n 16 above, p 131 and Pagone, see n 26 above, pp 83 and 84 
benefít was not intended by the tax norm, i.e. there is not a safe harbour, it.should be disregarded on the grounds that it constitutes an avoidance transaction. That is the underlying rational of all GAARs mentioned here. It is also present in the objectives of the tax shelters legislation in the US. ${ }^{32}$

\section{Testing the resulte: the tax benefit}

Merely using a contrived or artificial arrangement does not lead to tax avoidance unless this is clearly connected to the obtaining of a tax benefít of any kind. This connection is expressly stated in s. 15 of the LGT, as well as in raost GAARs. ${ }^{33}$ A tax benefít refers to any situation deriving in less taxes, be it in the form of lower tax rates, the application of deductions, the deferral of taxes, etc. The main thing is that there must exist a clear and logical link between the. obtaining of the benefít and the arrangements that have been carried out. Such benefits do not need to have been fully accrued, it will suffice if they are 'reasonably expected' in relationship with the scheme, something referred to with regard to the Australian GAAR proposal as the 'reasonable hypothesis' test. ${ }^{34}$

\section{E. The irrelevant role of testing the subjective intention or how form reveáis parpóse}

Tax avoidance is a purpose-based notion in the sense that there must be a clear and logical connection among all its elements, that are therefore oriented and directed to the obtaining of a tax benefít. But this does not mean that subjective intention should be proved. As Cooper pnts it, purpose can only be inferred from the taxpayer's actions: 'form reveáis purpose' ${ }^{35}$ The fact is, however, that whether or not the subjective intention of the taxpayer should count, and if so, to what extent, is still the object of much dispute. To some, the author included, it is perfectly irrelevant, to others, it is an essential element for the adequate functioning of anti-avoidance provisions. ${ }^{\prime 6}$ To a certain extent, the discussion is perfectly useless, for most of those favouring the 'subjective' element admit that it can only be proved with reference to the rest of the (objective) elements of tax avoidance. Section 15 of the LGT does point to the intention of the parts, but this should be understood as a reference to the purpose, not the motive? ${ }^{7}$ As $\mathrm{P}$. Millet illustrates the point, 'if a man points a loaded revolver at another's head and pulís the trigger, his motive may be greed, or jealousy, or revenge; his purpose is to kill; the effect is the victim's death. Only the two second elements matter in the field of tax avoidance.

\section{F. Purposive interpretation and tax avoidance: why shouid a GAAR be necessaryt}

The first and most important common element to all GAARs is that they provide an instrument for the tax administración to recharacterize a given arrangement by interpreting the tax legislation according to its purpose. To that extent, it has been often pointed out that excessive literalism when interpreting tax legislation, together with an excess of formalism when taking into account legal forms as defined in prívate law constitute one of the most important breeding grounds for the proliferation of tax avoidance schemes. ${ }^{39}$ As U. Paschen put it, regarding s. 42.1 of the AO, but clearly applicable to other GAARs, such a provisión:

'finds itself in a dialectic relationship between the freedom of legal forms or free will in prívate lay, on the one hand, and the ability to pay principies on the other, which at the same time is a clear reflection of the existing tensión between the formal and the material rule of law. ${ }^{40}$

In short, the key to adequately countering tax avoidance lays in the interpretation of the tax statutes.

\section{Notes}

32 The structure of thc Corporate Tax Shelters is slightly different, as ic departs from a quantitacive test, by comparing che expected benefits with the expected tax benefits, I will not deal with this interesting legislación here, see inter alia: Cooper, n 4 above, p 108 and other references quoted there

I3. IFS, see n 4 above; Ruiz Almendral and Seitz, n 7 above

4 The 'Ralph proposas that never actually made ir to Parliament but was subject to great discussions, intended to increase the concept of tax benefit, not only by linking it closer to the transaction, but by expanding it to all kings of tax deferrals; see more información at: Pagone, see n 26 above, pp 85 and 86

Cooper, see n 4 above, p 100

36 While Birk, see n 6 above, p 108; Passchen, see n 6 above, pp 19 and 20; Clausen, see n 28 above, p 1593 or Palao Taboada: 'Algunos problemas que plantea la aplicación de la norma española sobre el fraude a la ley tributaria', Crónica Tributaria 2001, no 98, p 131 consider it irrelevant, Falcón and Telia, see n 4 above, p 8 and Ferreiro Lapatza: 'El abuso en la aplicación de la norma tributaria en el Anteproyecto de Ley General Tributaria', Quincena Fiscal 2003, no 11, p 11 have maintained its importance Tipke, at n 6 above, p 1341 maintains the existence of the subjective intention, but docs not consider ic necessary to prove ic independently from the objective elements

7. Palao Taboada, see n 4 above, p 77; in order co fully assess this difference, the work of Avery Jones, 'Nothing either good or bad, but thinking makes ic so - che mental element in anti-avoidance legislation (1), Briiish Tax Keview 1983, p 18 is a must See also the distinction becween motive and purpose, with abundant references to the US case law, at: Martin J McMahon Jr: 'Beyond a GAAR: retrofitting the code co rewind in 21st century tax shelters', Tax Notes, 17 March 2003 , p 1733

Pecer Millett: 'Artificial Tax Avoidance The English and American Approach', British Tax Keview, 1986, p 330

w Walz, see n 14 above, p 226; Danzer, p 105; Fischer, see n 24 above, p 10; Andrés Báez Moreno: Normas Contables y Normas Fiscales en la determinación de la base imponible del impuesto sobre sociedades (Aranzadi, Pamplona, 2005 (fortheoming)); Ruiz Almendral and Zornoz Pérez: 'Interpretación, calificación, integración y medidas anti-elusión en la Ley 58/2003, de 17 de diciembre, General Tributaria', Estudios de Derecho Judicial 2005, no 57

(40) Paschen, see n 6 above, p 19 
Purposive interpretation is then the main instrument to recharacterize abusive transactions. ${ }^{41}$ This is a very important departing point for anti-avoidance doctrines, such as the business purpose test that I will deal with later. Its cornerstone is co regard taxation as a mainly practica! subject, based on certain uuderlying commercial and economic flows that must always be taken into account. ${ }^{42}$ By the same token, a GAAR is unsuitable to solve structural problems of a tax syscem. ín those cases, only a ref'orm of the pertinent law or provisión can solve the problem.

But interpretation alone will not always be enough to solve an avoidance situation. There are different means to curb avoidance transactions. Most of the time, an adequate interpretation will suffice to that end. To adequately recharacterize an operation, by interpreting both the pertinent tax provisions and the arrangements carried out by the parties will serve to guarantee an adequate (fairer, etc.) distribution of the tax burden. But the words cannot be interpreted ad infinitum and in an área that falls within the rule of law the interpreter, the tax authorities in this case, cannot go beyond the possible sense or meaning (Wortsinn) of the words, although they may, or even must, go beyond their literal meaning (Wortlaut). ${ }^{43}$ The words may clearly allow for the tax regime that the avoider was seeking for to apply, but not the purpose of the tax norm taken as a whole. There will be avoidance cases where the ploy invented by the parties fall perfectly within the scope of the meaning of the words, and even to a certain excent, ro $\mathrm{i}$ es significance. If that is che case, merely interpreting the words of the stacute will not help. A reorganisation carried out for the only purpose of avoiding taxes, may in principie be a reorganisacion in all its elements, the actual shares were exchanged, the flows of monies did oceur and nothing was by itself artificial or oucside the literal meaning of the statutes. Either the court develops a very elabórate purpose-oriented interpretation and disregards the operation for tax purposes, if it does not fit the objectives of the tax free regime, or, if che coures are not clearly used to interpreting tax norms in such a way, but racher to depart from or take as valid operations that, from an strictly prívate law point of view are perfectly valid, then a GAAR will be necessary, as only such a provisión can help re- establish the adequate order of law and ignore the operation only with regard to the taxes to be applied to it. In short, a GAAR implies taking a step further from interpretation, take a distance from the tax provisión itself and consider both the tax norm and the arrangements as a whole. If the elements previously analysed are present, then the tax authorities may disregard the operation for tax purposes.

In the Spanish context, a GAAR is especially necessary, given the strong tendeney of the courts, and the tax administration, either to carry out a very literal approach to the interpretation of tax norms, or to reason that a certain arrangement or act is an avoidance act, but without actually applying the anti-avoidance provisión, which among other effeets, diminíshes the principie of legal certainty. ${ }^{44}$ In many cases, che confusión has lead co admitting the possibility of imposing sanctions to tax avoidance schemes, despite the fact that both the previous as the present Spanish GAAR expressly reject that possibility. ${ }^{45}$

On the other hand, GAARs also serve other functions, such as being a sort of guideline for the courts, créate an ad terrorem effect on taxpayers, enhance the certainty of the law by clearly establishing the consequences for the taxpayer and, as s. 15 of the LGT does, the process that the tax administration must follow in order to recharacterize a given arrangement. ${ }^{40}$ En passant, these arguments also serve as an answer to the 'mantra-like' repeated claim that GAARs are too vague or imprecise to meet the strict standards of the rule of law. As Cooper points out, the claim has becorne so universal that most commentators do not even bother explaining exactly why it is that they should be so imprecise. ${ }^{47}$ On the contrary, the fact is that there are sufficient elements that bring a great amount of precision to these provisions.

Nonetheless, as I pointed out in the introducción to this article, these are harsh times for GAARs. On the one hand, an ever more complicated international context is increasingly moving governments to design and apply specific anti-avoidance rules, that may simplify the work of tax authorities. This of course poses new questions as to how exactly these rules relate to international treaties. ${ }^{48}$ On the other hand, the scope of GAARs is also being questioned as a consequence of European law, and specifically, as we

\section{Notes}

4) IFS, see n 4 above, pp 9 and 10 Scc chis idea at che Canadian Supremo Court's case Stubart Investments Ltd. $v$ The Queen (1984) CTC 294; see also, inter alia, Arnold, n 4 above, p 542; Vaniscendael, 'Legal framework for taxation' in Thuronyi (ed )i Tax Law Design and Drafting (Kluwer Law, The Hague, 2000), pp 54 and 55 ; Cooper, see $\mathrm{n} 4$ above, p 85

4. Milletr, see n 38 above, p 331

45. Claus Wilhelm Canaris: Die Feststellung van Liicken im Gesetz (Duncker \& Humblot Berlín, 1983), pp 88 and 89

44 Scc many examples, inter alia, in Zornoza Pérez, ti 12 above; Palao, see ns 4 and 8 above; Ruiz Almendral and Seitz, n 7 above

45 See examples at: García Novoa: La cláusula antielusiva (Marcial Pons, Madrid, 2004); Báez Moreno and Hugo López : 'Nuevas perspectivas generales sobre la elusión fiscal y sus consecuencias en la derivación de responsabilidades penales: a propósito de la sentencia del Tribunal Supremo de 30 de abril de 200 ?', Revista Estudios Financieros 2004

45. See these arguments, inter alia, in: Arnold, n 4 above, p 553; IFS, n 4 above; Cooper, n 4 above, p 88

Cooper, n 4 above, p 93

48. I will leave the study of these problems out, as it clearly surpasses the scope of this arricie On chis regard, see, Ínter alia: Adolfo j Martín Jiménez, 'Domestic AntiAbuse Rules and Double Taxation Trcaties: a Spanish Perspective', I and II, Bulletin. International Bureau of Fiscal Documentation 2002, nos II and 12 
will now see, as a consequence of the ECJ case law on this matter.

\section{Tax avoidance in the European context}

Direct taxes may not have been harmonised (yet), but many of their features have already been the subject of a certain level of indirect harmonisation via the ECJ case law, which basically derives from the obligation, for all Member States, to exercise their tax authority in compliance with the non-discrimination principie. Furthermore, the Court. has made it clear that:

'the prohibition on Member States establishing restrictions on the freedom of establishment also applies to tax provisions. According to consistent case-law, even if, in the current state of Community law, direct taxation does not as such fall within the scope of the Community's jurisdiction, Member States must nevertheless exercise their retained powers in compliance with Community law. ${ }^{49}$

In a nutshell, the freedoms constitute 'authentic rights to access the markets of the different Member States in conditions identical to the national economic agents, which implies the elimination of all discriminatory rules and of burdens of any kind that, in the tax arena, may be imposed upon the actors of cross borders operations' ${ }^{50}$ It is important to bear in mind this last sentence, for it is only from this perspective that the ECJ case law on tax avoidance may be fully understood. Along this line, the ECJ has often rejected tax measures that, albeit not directly discriminatory, were regarded as 'burdens' restricting the free access to the European markets.' ${ }^{1}$

The full extent and consequences of this case law is not easy to assess, for it is not always clear when a given tax norm or provisión may fall under that doomed área and be considered against EU law. One of the major problems in interpreting the ECJ Decisions is the growingly blurred distinction between restrictive and discriminatory measures. ${ }^{52}$ The difference in their tax regime is crucial, as the first can only be justified by the reasons expressly admitted in the Treaty, while restrictive measures can only be accepted under certain circumstances of general public interest. The concept of restriction can be easily applied to a cross-border movement, but it is not always understandable with regat'd to a taxing regime that involves many different and interrelated taxable facts, unless we maintain a nineteenth century concept of tax that merely views it as a burden. This of course entails that the reasoning when examining one or the other be totally different: while the principie of non-discrimination requires the comparison of situations, the nonrestriction approach merely needs to analyse whether the measure is, directly or indirectly, an obstacle, and whether that can be accepted by the existence of an exemption. $-^{\wedge^{3}}$ This distinction is easier when applied to indirect taxes, among other reasons, because of the structure of the Treaty. ${ }^{54}$ But the most relevant consequence, totally pertinent to our analysis, is that the non-discrimination approach allows for a much greater leeway for Member States to develop, and therefore also to protect, their tax systems. As F. Vanistendael very graphically explains, the restriction concept:

'views the EU market as a huge snooker table, where all the economic balls roll smoothly from one córner to the other. In the non-discrimination approach it is sufficient that cach snooker player can play under the same conditions at different snooker tables. In the non-restriction approach all players are playing from different corners at the same snooker table. ${ }^{55}$

In practice, though, the differences among the two approaches has been blurred by the ECJ case law.

Another problem that arises when analysing the ECJ case law is that, especially in the field of direct taxes, the Court often eludes qualifying a given measure as discriminatory but simply analyses whether it can be justified or not on the grounds of the general interest, which of course only adds to the confusión. Among the general interest exceptions that may justify a given tax provision, the Court has dealt with the need to establish

\section{Notes}

Ínter alia: C-279/93, Schumacker para 21; C-264/96, ICI, para 19; C-436/00 X ana Y if para 32, C-9/02, Lasteyrie du Saiilant, para 44

*0 Calderón Carrero and Martin Jiménez: 'Jurisprudencia del Tribunal de Justicia de las Comunidades Europeas en materia de IRPF', AAVV: Manual del Impuesto sobre la Renta de las Personas Físicas (Instituto de Estudios Fiscales, Madrid (fortheoming)), p 4 For a thorough analysis on the Court's case law on chis issue, see: Martín Jiménez and Calderón Carrero: Imposición Directa y no discriminación comunitaria (EDERSA, Madrid, 2000), p 87; Calderón Carrero: 'Algunas consideraciones en torno a la interrelación entre los convenios de doble imposición y el derecho comunitario: ¿hacia la 'comunítarización' de los CDIs?', Crónica Tributaria 2002, nos 102 and $103, \mathrm{p} 23$

50 There is abundant literature on the ECJ case law in chis arca; Ínter alia: Caamaño Anido, Calderón Carrero and Martin Jiménez: jurisprudencia del Tribuna! de Justicia de las Comunidades Europeas (1996-!999)(LÚ Ley, Madrid, 2000), p 237; Ruiz Almendral: 'El Impuesto sobre la Renta de las Personas Físicas en el proceso de armonización fiscal en la Unión Europea", Revista Española de Derecho Europeo 2002, no 3, p 432

52 Whether or not this distinction should be made at all is still the object of much controversy, as shown: CALDERÓN CARRERO; MARTÍN JIMÉNEZ: 2004, 77 footnotes 92 and 93 )

S3 VAN1STENDAEL: 2003, 137

54 VANLSTENDAEL: 2003, 138; the author shows a number of inconsistencics of applying both criteria, or a mixture of them, to direct taxes; see also: Calderón Carrero and Martin Jiménez: 'Las normas antiparaíso fiscal españolas y su compatibilidad con el derecho comunitario: el caso especifico de Malta y Chipre tras la adhesión a la Unión Europea', Crónica Tributaria 2004, no 111, p 77

sf Vanistendael: 'The comparibility of the basic economic freedoms with the sovereign national tax systems of the Member States', EC Tax Review 2003, no 3, $\mathrm{p}$ 139 
tax controls, the need to curb tax avoidance, or to guarantee the coherence of the tax system. The need to safeguard tax revenues has also been examined, but never accepted as a justification in this regard. ${ }^{56}$

Furthermore, in the last decade, a large number of specific anti-avoidance measures have been the target of a series of ECJ's decisions, to the point that it is not clear exactly what the future for some of these measures may be. ${ }^{57}$ At this moment there is no legal definition of tax avoidance in any EU norm. At least, not formally, for the directives that expressly mention the concept mereíy establish the basis for Member States to introduce and apply their own anti-avoidance rules. However, at the same time they also set the boundaries for the establishment of such rules. ${ }^{58}$ Thus, Art. 1.2 of the Parent-Subsidiary Directive (90/435/ EEC) allows Member States 'the application of domestic or agreement-based provisions required for the prevention of fraud or abuse', while Art. 27.1 of the Sixth Directive (77/388/EEC) allows them 'to introduce special measures for derogation from the provisions of this Directive, in order to simplify the procedure for charging the tax or to prevent certain types of tax evasión or avoidance'. Article 11.1a of the Merger Directive (90/434/EEC) goes further and introduces the críterion of 'valid commercial reasons', stating that:

'a Member State may refuse to apply or withdraw the benefit of all or any part of [the special rules applicable to certain qualifying reorganisations] where it appears that the merger, división, transfer of assets or exchange of shares: (a) has as its principal objective or as one of its principal objectives tax evasión or tax avoidance; the fact that one of the operations referred to in Article 1 is not carried out for valid commercial reasons such as the restructuring or rationalization of the activities of the companies participating in the operation may constitute a presumption that the operation has tax evasión or tax avoidance as its principal objective or as one of its principal objectives.'

As we will see, departing from these provisions, and in the light of the fundamental freedoms, the ECJ has actually construed a concept of tax avoidance.

Thirdly, the Council Directive on a common system of taxation applicable to interest and royalty payments made between associated companies of different Member States (20Q3/49/EC), also contains a special clause on 'fraud and abuse', which allows the application of domestic anti-abuse provisions. Thus, Art. 5 establishes that:

1. This Directive shall not preclude the application of domestic or agreement-based provisión required for the prevention of fraud or abuse. 2. Member States may, in the case of transaction for which the principal motive or one of the principal motives is tax evasión, tax avoidance or abuse, withdraw the benefits of this Directive or refuse to apply this Directive.'

On the other hand, the Council Directive on taxation of savings income in the form of interest payments (2003/48/EC) does not really mention the concept of tax avoidance, but refers to it in a very indirect way. First, it allows Member States to 'take all requisite measures to prevent infringements of nacional law and regulations, in particular in the field of taxation'. The second mention is a sort of warning: 'In accordance with Article 58(3) of the Treaty, the provisions of Member States' tax law designed to counter abuse or fraud should not constitute a means of arhitrary discrinúnation or a disguised restriction on the free movement of capital and payments as established by Article 56 of the Treaty" (author's emphasis). Thirdly, the Directive refers to the exchange of information as the main instrument to guarantee the effective taxation of interest payments. As effective as such exchange may be to that end, ${ }^{59}$ the absence of any reference whatsoever to curbing tax avoidance through other methods is remarkable.

Finally, the Mutual Assistance Directive (77/799/ EEC) intends to establish a sort of support to help curb fraud and avoidance." ${ }^{0}$ Of course the Mutual Assistance Directive cannot replace domestic anti-abuse rules, but may significantly reinforce them, and has the

\section{Notes}

6 Calderón Carrero and Martín Jiménez, see n 52 above, pp 78-80

With regard ro the (in)compatibility of Member Stares' anti-treaty shopping measurcs, see: Félix Vega Borrego: Las medidas contra el Treaty Shopping (Instituto de Estudios Fiscales, Madrid, 2003), p 350 For the conscquences for the Spanish thin-cap measures, regarded as specific anti-avoidance provisions, see recently: Calderón Carrero: Precios de Transferencia e Impuesto sobre Sociedades (Tirant lo blanch, Valencia, 2005), p 53

A recent analysis of the FCJ in the field of anti-avoidance legislador! can be round at: Calderón Carrero and Martin Jiméniz, see n 50 above, p 62.

Garcia Prats, see n 7 above, p 204

6 See in this regard the comprehensive study of Calderón Carrero: Intercambio de información y fraude fiscal internacional (Centro de Estudios Financieros, Madrid, 2000), p 31

*2 The motivación of the Directivy clearly illustrares the panorama: 'Whereas practices of tax evasión and tax avoidance extending across the frontiers of Member States load to budget losses and violations of the principie of fair taxation and are hable to bring about distortions of capital movements and of conditions of competition; whereas they therefore affect the operation of the common market; whereas, for these reasons the Council adopted on 10 February 1975 a resolution on the measures to be taken by the Community in order to combat international tax evasión and avoidance (OJ No C 35, 14 2 1975, p l); Whereas the internarional nature the problem means that national measures, wliose effect does not extend beyond national frontiers, are insufficient; whereas collaboration betvveen administrations on the basis of bilateral agreements is a

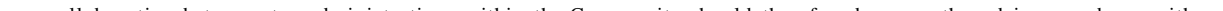
Community should therefore be sriengthened in accordance with common principies and rules; 
clear advantage of being perfectly in line with the development of the fundamental freedoms. ${ }^{61}$

Despite the fact that the EU law does not directly contain its own anti-avoidance provisions, as it merely sets the basís for Member States to establish theirs, the existing case law on the aforementioned provisions points to a concept of tax avoidance. Such a concept, of course, has only been construed through a series of decisions, which have introduced a de facto harmonisation in this matter. So much ink has already flowed on these decisions. In the following lines, I will look into this case law only to the extent that it will help illuminate the concept of tax avoidance developed by the ECJ and contrast it with the concept followed by most GAARs. It is true that, at the moment, the Court has only ruled against specific anti-avoidance provisions, so that no GAAR has been the direct object of any decisión, however, a quick look at how the land lies in this matter tells us that the time for the general anti-avoidance rules may not be too far. It is then pettinent to take a look at what the ECJ has been saying about tax avoidance in order to draw the pertinent consequences that are bound to affect the new Spanish GAAR, and for that matter, most European rules along this line.

In principie, the definition of tax avoidance that derives from the ECJ case law should only affect those cases where a transaction is carried out in a 'European context'. However, given the broad interpretation developed by the Court with regard to its own scope of authority (Leur-Bloem, inter alia), the relevance of such a concept is bound to have a greater impact than what could be first envisaged.

As I have mentioned above, the Court fully acknowledges that the objective of countering tax avoidance is generally accepted by EU law. At the same time, the Court has always rejected the argument of there being 'a risk' of tax avoidance to establish a measure that limits any European fundamental freedom. ${ }^{62}$ However, tax avoidance can act as an exemption of general interest in order to justify a restriction on a fundamental freedom: 'the need to safeguard the cohesion of a tax system, the prevention of tax evasión and the effectiveness of fiscal supervisión constitute overriding requirements of general interest capable of justifying a restriction on the exercise of fundamental freedoms guaranteed by the Treaty'. ${ }^{63}$ At any rate, anti-avoidance measures of any kind must fít within the boundaries of the ECJ doctrine on such freedoms. Very often the freedoms opérate as a sort of safe harbour rule, which may qualify transactions as 'protected' in ternas of tax avoidance measures. ${ }^{64}$

A number of different factors determine the final argumentation to be followed by the Court. They can be summarised as follows.

" Whether or not the tax avoidance provisión has previously been established or authorised in a Directive. In practice, the Court has interpreted the anti-avoidance measures contained, albeit indirectly, in Directives by developing its own concept of tax avoidance. With regard to the ParentSubsidiary Directive, where Art. 1.2. clearly states that the Directive 'shall not. preclude the application of domestic or agreement-based provisions required for the prevention of fraud or abuse', the Court has limited the interpretation of this clause to the content of Art. 3.2 of the Parent-Subsidiary Directive $^{65}$ by stating that the first Article 'is a provisión of principie, the content of which is explained in detail in Article 3(2) thereof. Thus, Article $3(2) \ldots$ is aimed in particular at counteracting abuse whereby holdings are taken in the capital of companies for the solé purpose of benefiting from the tax advantages available and which are not intended to be lasting. In those circumstances, it is not appropriate to refer to Article 1(2) of the Directive in interpreting Article 3(2)' (Denkavit, accumulated cases C-283/94, C291/94 and C-292/94, para. 31 (author's emphasis)). It has been said that Denkavit views Art. 3.2 as containing a lex specialis that is also subject to a strict and literal interpretation. ${ }^{66}$ The fact is, however, that the Court does much more than that,

\section{Notes}

6. This is why the FCJ has defended a very broad concept of avoidance and fiscal evasión in the framcwork of the Directive 77/799, in clear contrast with the concept maintained oucside this norm; see for instance the case Whl, C-420/98, 13 April 2000; see a comment on this case at Calderón Carrero, n 59 above, pp 318-319

2. the risk of tax avoidance cannot be relied upon in this context Article 52 of the EFC Treaty does not permit any derogación from the fundamental principie of freedom of establishment on such a ground' (Commission/France, C-270/83, para 25)

63 In $\mathrm{X}$ and $Y_{i} I(\mathrm{C}-436 / 00$, para 51) In that case, the Court rejected a Swedish anti-avoidance rule which ainied at controlling the transfers of assets and the like to corporations located in other Member States at very low pric es In the Court's opinión, the provisión was inappropriate - i e not proportionate to its objeccive and it thercforc caused a discriminación against those transactions concluded outside the country, in terms that it considers to be contrary to the freedom of establishment

to That was spccially evident in the $I C_{i}$ case, where the Court developed a 'creative' or rather extensive interpretación of the freedom of establishment by interpreting it in the light of the ultímate objective of the treaty: the realisation of an interior market; see in this regard: Caamaño Anido and Calderón Carrero, $\mathrm{n} 5$ above, pp 21 and 24 , regarding the $I C I$ case $(264 / 96)$

45 Which states: 'By way of derogation from paragraph I, Member States shall have the opción of not applying this Directive to companies of that Member State which do not maintain for an uninterrupted period of at least two years holdings qualifying them as parent companies or to those of their companies in which a company of another Member State does not maintain such a holding for an uninterrupted period of at least two years'

Francois Hoenjet: 'The Leur-Bloem judgmenc: the jurisdiction of the European Court of Justice and the interpretación of the anti-abuse clause in the Merger Directive', EC Tax Keview 1997, no 4, p 212 
and goes well beyond the literal meaning of the words, as it limits the scope of Art. 1.2 to that of Art. 3.2. The consequence is a practical 'mutation' of the concept, and a clear restriction of the reference that Art. 1.2 operates to national GAARs. To some, thís ímplies that no national antiavoidance provisión can be applied to this range of cases. ${ }^{67}$ More likely, however, as J. Calderón puts it, the Decisión does point to a priority application of the specific anti-avoidance clauses established in the Directive over the domestic ones. The latter must depart from and take into account the material requirements set in the Directive, such as the hokling period clause. ${ }^{\text {e }}$

The Court has also substantially reduced the scope of the anti-avoidance clause contained in the Merger Directive, basically by defining in very strict terms the concept of valid commercial reasons. For the sake of clarity and completeness, I deal with this later on, in a special section, by way of comparing it with the 'traditionaP busíness purpose doctrine. In short, it is clear that the Court is most restrictive when interpreting anti-avoidance clauses contained in the Directives or at least originated by them.

Whether the measure intends to establish some kind of tax control to monitor the flow of revenues. Clearly, the Court bestows a different treatment dependíng of whether the measure is anti-avoidance, or has as its tnain intention to establish control measures, such as was pointed out in Futura Parücipations (C-250/97). ${ }^{69}$

Whether, or to what extent, the measure can be regarded as a restriction. As I have pointed out earlier on, the Court not only does not rnake the distinction between restrictions and non-discrimination very clear, but has been widely (and confusingly) applying the first to direct taxes. The main problem is that the restriction concept can only be applied in an 'all or nothing' manner, as it does not require, ñor permit reaily, the comparison in terms of similarity in different situations. When applied to income taxes, not only this criterion is not clearly understood, but gives rise to a number of questions that turn around a basic, quasi-philosophical one: what exactly are taxes? Viewed from a strict non-restriction concept, any tax is a burden that will hinder the free movement across borders. Of course that would mean going too far, but the direction adopted by the Court seems to flirt with that idea. ${ }^{70}$

To confuse matters further, all these criteria or elements are intertwined in the reasoning of the ECJ so that there is not always a clear or straight path to follow. In the end, the only key criterion is the proportionality of a given measure to its purported objective, which of course is also extremely flexible. ${ }^{71}$

Bearing the above considerations in mind, I will now merely point out some of the basic conclusions that may be drawn from the existing decisions, in order to assess fully the European concept of tax avoidance.

In principie, 'exit taxes' are forbidden within the EU. The Court has clearly established that transactions or arrangements that clearly constitute an exercise of the fundamental freedoms cannot be considered avoidance for that matter; that is, exit taxes are forbidden by EU law when they are merely based on the fact of the exit company or person moving to another Member State. So, 'the transfer of a physical person's tax residence outside the territory of a Member State does not, in itself, imply tax avoidance'. The Court categorically states that: 'tax evasión or tax fraud cannot be inferred generally from the fact that the transfcree company or its parent company is established in another Member State and cannot justify a fiscal measure which compromises the exercise of a fundamental freedom. guaranteed by the Treaty' (X and $\mathrm{Y} / /$, para. 62, Lasteyrie, para. $51^{72}$ ).

The reason these taxes are basically forbidden, is that they are considered restrictive. This poses the problem of the very broad terms employed by the Court when defining what can constitute a restriction; the Court refers to it claiming the 'dissuasive effect' of a provision (Lasteyrie, para. 45). Or the fact that it mav hinder or rnake less attract'we the exercise of

\section{Notes}

Brigitte Knobbe-Keuk: 'The EC corporace tax direct i ves - anti-abuse provisions, direct effect, Germán implementation law', Intertax 1992, nos 8-9, p 489; although chis last author introduces a nuance, in the sense that ic merely modifies the interpretación of che anti-avoidance provisión

* Calderón Carrero: 'A Post-Denkavit Review of the Anti-Directive Shopping Rules in Spain: eommencs on a case involving US and Dutch Parent companies', Tax Notes International (fortheoming), p, 12 A similar interpretación had been defended by: Wolfgang Schon: Die Auslegung europaischen Steuerrecbt. Das harmonisierte Steuerrecbt zwischen nationalem Zivilrecht und europaischem Gemeinscbaftsrecht, Verlag Dr Otto Schmidt (Koln, 1993), $\mathrm{p} 70$ and Dennis Weber: 'A closer look at the general anti-abuse clause in the Parent-Subsidiary Dircctive and the Merger Directive', EC Tax Review 1996, no 2, p 64, whose views may have had an influence on the Court See also: Weber: 'The first steps of the ECJ concerning an abuse-doctrine in the field of harmoni/ed direct taxes', EC Tax Review 1997, no 1 , p 30

* In the context of fiscal control measures, the proportionality of a given provisión is measured in the light of che Directive 77/799; Caamaño Anido and Calderón Carrero, see n 5 above, p 30 See, regarding the Futura case, vvhere a tax control measure was at stake: Caamaño Anido, Calderón Carrero and Martín Jiménez, see $\mathrm{n} 51$ above

70. Vanistendael, scc $\mathrm{n} 55$ above, p 140

7) inter alia in: X and Y l! (C-436/00, para 49); Lankhorst-Hohorst (C-324/00, para 33), or Futura Participations (C-250/97, para 26); see in chis regard: Calderón Carrero and Martín Jiménez, see n 52 above, pp 80 and 81

72 In Lasteyrie du Saillant, the ECJ declared void a French exir tax on the grounds that it infringed tipon the freedom of establishment The main argument was that it constituted a burden to the exercise of the said freedom which could however not be justified with reference to the purpose of countering tax avoidance hecausc the measure itself did not only target contrived or artificial arrangements, but any sicuation where the taxpayer decides to abandon the country and move to another Member State What the Court attacks in Lasteyrie, is the assumption that leaving the country may give place to avoidance, thus granting the same treatment to situations regardless of vvhecher or not they actually incur in such avoidance 
fundamental freedoms (Centros, C-212/97, para. 34 (author's emphasis)).

Tax avoidance provisions must be proportionate to their objective. To the Court, this means that measures that may affect the exercise of fundamental freedoms 'must fulfil four conditions: they must be applied in a non-discriminatory manner; they must be justified by imperative requirements in the general interest; they must be suitable for securing the attainment of the objective which they pursue; and they must not go beyond what is necessary in order to attain it' (Centros, C-212/97, para. 34). Specifically, Member States may not presume avoidance unless they intend to prevent wholly artificial arrangements to circumvent national tax legislation. This, for instance, cannot be just presumed: in the establishment of a subsidiary abroad (ICI, C-264/96); any situation in which a parent company has its seat abroad (Lankborst, C-324/00); the establishment of a parent company or of a subsidiary abroad (X and YII, C-436/00) or a situation when an individual merely transfers his/her residence to another Member State (Lasteyrie, C-9/02).

The Court has also pointed out that merely trying to guarantee revenues is not enough of a justification, for 'a reduction of revenue ... is not one of the grounds lísted in Article $46 \mathrm{EC}$ and cannot be regarded as a matter of overriding general interest which may be relied upon in order to justify unequal treatment that is in principie incompatible with Article 52 of the Treaty' (ICI, para. 28; Saint-Gobain, para. 50). The Court makes it clear that protecting revenues is not a criterion enough as to safeguard a given provisión. Of course what is not so evident is when can we conclude that a would-be anti-avoidance provisión has that as one of its purposes. We must bear in mind that, at least as a matter of principie, anti-avoidance rules do not have as their primary objective the protection of revenues. This of course will come as a natural consequence, but such an objective would not justify their existence in the light of most EU Member States' constitutions. It is the protection of the principie of equality, of the adequate distribution of public burdens among citizens that constitutionally justifies the introduction of anti-avoidance measures. To the extent that every tax has as one of its main purposes the obtaining of revenues, and is therefore legitímate because of it, it logically follows that any measure that intends to protect the tax system will have a similar objective. In short, it is not clear exactly what the Court is referring to. This can only be explained as a response given to the parties that brought up the argument in the first place.

Every anti-avoidance provisión must be interpreted in accordance to the EC law vvhere they must be applied. The Court then establishes a purposive interpretation that merely, or mainly, takes into account the EU law. Therefore, although:

'it is true that according to the case law of the Court a Member State is entitled to take measures designed to prevent certain of its nationals from attempting, under cover of the rights created by the Treaty, improperly to circumvent their national legislation or to prevent individuáis from improperly or fraudulently taking advantage of provisions of Community law...However, although, in such circumstances, the national courts may, case by case, take account - on the basis of objective evidence - of abuse or fraudulent conduct on the part of the persons concerned in order, where appropriate, to deny them the benefit of the provisions of Community law on which they seek to rely, they must nevertbeless assess such conduct in the light of the objectives pursued by tbose provisions' (Centros, C-212/97, paras. 24 and 25 (author's emphasis)).

The avoidance transaction must be clearly so. In the Court's opinión, only those provisions aimed at dismounting artificial or contrived transactions, undertaken for the purpose of obtaining a tax benefit, may be targeted by anti-avoidance rules; i.e. 'designed to exelude from a tax advantage purely artificial schemes designed to circumvent [any Member States'] tax law' (X and $Y$ II, para. 61; Lasteyrie, para. 50). Artificial is then defined in terms that may be very similar to the concept of sham.

Furthermore, there must be a clear-cut cause-effect relationship between the arrangement transaction and the tax benefit. Every anti-avoidance measure must establish a precise link between the purported taxpayer's objective of obtaining a certain benefit and an artificial arrangement:

Tn that regard, the national courts may, case by case, take account - on the basis of objective evidence - of abuse or fraudulent conduct on the part of the persons concerned in order, where appropriate, to deny them the benefit of the provisions of Community law on which they seek to rely, but they must nevertheless assess such conduct in the light of the objectives pursued by those provisions' (X and $\mathrm{Y} / /$, para. 42).

Henee, the Court rules against specific anti-avoidance provisions that take into account a lump-sum group of cases, without verifying whether or not there is avoidance. A general assumption, even if it is iuris tantum, that certain transactions, carried out under circumstances that show that the whole arrangement was entered into in order to save taxes (low price, foreign Corporation...) are avoidance transactions is rejected up-front by the Court as long as the parts in the transaction are carrying out the exercise of the said fundamental freedom.

The analysis and definition of the economic motives must depart from the fundamental freedoms; there is a sort of 'fundamental freedoms-business purpose test'. The Court has carried out a very strict interpretation of any kind of anti-avoidance measures. In order to fully assess the implications of this case law I will compare the two cases that epitomise, respectively, the business purpose test doctrine - Helvering $v$ Gregory and the anti-avoidance opinión of the Court regarcling tax free corporate reorganisations - Leur-Bloem which constitutes an authorised interpretation of the economic motives criterion enshrined in Art. 11 of the 
Merger Directive. Mutatis mutandi, both Mrs. Helvering and Mrs. Gregory carried out a tax-free reorganization $i n$ order to advantage of the special tax benefits established in the pertinent provisions.

\section{An example: the business purpose test 'at work': a comparíson of Helveríng $v$ Gregory and Leur-Bloem}

The most representative case regarding the business purpose test doctrine is usually cited as Helvering $v$ Gregory $\rho^{\beta}$ The business purpose test doctrine has had a vvide influence outside the US; for example, it served as a basis for the inflection point that lead to a new approach, the 'new realism', epitomised by the Ramsay case (W T Ramsay $v$ Inland Revenue Commissioner $s^{1, \ldots i}$ ) that purported a purposive interpretation of tax statutes which has proved very effective in countering tax avoidance despite no GAAR. ${ }^{75}$

To a ccrtain extent, che facts resemble LeurBloem's. Ms. Gregory carried out a corporate reorganisation without any other business purpose than to save taxes $/^{6}$ The arrangement, she claimed, was not really artificial, in the sense that. it had been effectively carried out following the strict terms of the law establishing the tax exemption, that defined a reorganisation as 'a transfer by a Corporation of all or a part of its assets to another Corporation if immediately after the transfer the transferor or its stockholders or both are in control of the Corporation to which the assets are transferred'. That is, no minimal holding period or any other requisite is established in the law. The Court disregarded the operation, following this track of thought.

(1) The arrangements are recharacterized not only beca use they lack an autonomous commercial or business purpose, as could be concluded at first sight, but because they are artificial, inadequate to the economic end, except for the result consisting of a tax benefit. In the words of the Court, artificiality and lack of valid economic reasons are two sides of the same coin. Therefore, although the corporation was indeed created, following the text of the norm, 'that corporation was nothing more than a contrivance to the end last described [to obtain a tax benefit]. It was brought into existence for no other purpose; it performed, as it was intended from the beginning it should perform, no other function'. And this is why the operation is disregarded:

'In these circumstances, the facts speak for themselves and are susceptible of but one interpretation. The whole undertaking, though conducted according to the terms of [the pertinent provisión] was in fact an elabórate and devious form of conveyance masquerading as a corporate reorganización, and nothing else. The rule which exeludes from consideration the motive of tax avoidance is not pertinent to the situation, because the transaction upon its face lies outside the plain intent of the statute. To hold otherwise would be to exalt artifice above reality and to deprive the statutory provision in question of all serious purpose" (author's emphasis).

(2) The business purpose doctrine adopts an objective perspective, without íurther analysing the actual will or motive of the taxpayer with regard to saving taxes. The US Supreme Court admits that the subjective intención of the taxpayer will not be taken into account if the arrangement has actually been undertaken; 'It is quite true that if a reorganisation in reality was effected within the meaning of [the pertinent provisión] the ulterior purpose mentioned will be disregarded'.

(3) The business purpose test is nothing more, nor less,

\section{Notes}

This case had been previously decided ac che Seeond Circuit Court of Appeals, where Judge Learned Hand had disregarded che operación [293 US 465, 468], which was rejected by the Board of Tax Appeals, which uphcld the petitioner's view [27 BTA 223] Finally, the case made ic co the US Supreme Court, that assumed all che arguments employed ac che Court of Appeals [(1935) 293 US 465]; the business purpose test doctrine can also be found, inter alia, ac: Helvering $u$ Clifford, 309 US 331 (1940), 1940-1 CB 105; Zmuda v Commissioner, 731 F 2d 1417 (9th Cir 1984); Segal v Commissioner, 41 F 3d 1144, 1148 (7ch Cir 1994); Yosha u Commissioner, 861 F 2d 494 (7ch Cir 1988); ACM Partnersbip v Commissioner, 157 F 3d 231, 246-47 (3d Cir 1998)

74 Henee departing from the excessive literalism that had been dominant in the case law, and that was clearly reflected in Duke of Westtninster, quoted above The influence of the business purpose test doctrine is also very clear in Furniss v Dawson (1984) 55 TC 324 The nmin elements in Furniss are similar to Helvering's. See a full account of the influence of the business purpose test in che UK at: Millett, see n 38 above, p 332; see also Nevermann, n 16 above, p 180; Maicolm Gammie: 'Tax Avoidance and the Rule of Law: a perspective from the United Kingdom', i» Graeme Cooper \{ed.j, Tax Avoidance and the Rule of Law (International Burean 'Tax Avoidance and the Rule of Law: a perspective from the United Kingdom', $i$ » Graeme Cooper \{ed.j, Tax Avoidance and the Rule of Law (International Burean
of Fiscal Documentation, Amsterdam, 1997), p 189; Jefferson Vanderwolk, 'Purposive Interpretation of Tax Statutes: Recent UK Decisions on Tax Avoidance Transaction', International fítreau of Fiscal Documentation 2002, p 71,

Another example of business purpose test, as applied too to a company rescructure, can be found in che Auscralian case FCT $v$ Peabody [94 ATC 4663]; see a chorough commencary on that case at: Passanc, n 17 above, p 455

3. Vanderwolk, see n 74 above, pp 75 and 76 A different view is that adopted by che 1FS, see n 4 above, pp 14 and 15, that maintains che limitación of case law when fighting cax avoidance

4 As described in che case brought before che US Supreme Court, the facts are che following: Ms Gregory was che owner of all che stock of United Mortgage Corporation, which held among irs assecs 1,000 shares of che Monitor Secundes Corporation For the solé purpose of procuring a transfer of these shares to herself in order co scll them fot her individual profit, and, at the same tirne, diminish the amount of income tax which would result from a direct transfer by way of dividend, she soughc to bring abouc a cax free 'reorganisation' under s 112(g) of the Revenue Act of 1928 To that end, she caused the Avcrill Corporation to be organised under the laws of Delaware on 18 September 1928 Three days later, the United Mortgage Corporation cransferred to the Avcrill Corporation the 1,000 organised under the laws of Delaware on 18 September 1928 Three days later, the United Mortgage Corporation cransferred to the Avcrill Corporation the 1,000
shares of Monitor stock, for which all the shares of the Avcrill Corporation were issued to the petitioner On 24 September the Averill Corporation was dissolved, and liquidated by discribucing all its assets, namely, the Monicor shares, co the petitioner No other business was ever transacted, or intended to be transacted, by that company Petitioner immediately sold che Monicor shares for USD 133,333 33 She returned for taxation, as capital net gain, che sum of USD76,007 88, based upon an apportioned cost of USD57,325 45 It is not disputed chat if the interposition of the so-called reorganisation was ineffective, pecicioner beca me Hable for a much largor cax as a result of the transaction 
than a type of teleological interpretación applied to tax norms, which pays attention to the underlying economic basis of the pertinent act or arrangemenr. 'The question for determination is whether what was done, apart from the tax motive, was the thing which the statute intended..$^{7}{ }^{\prime}$ Ms. Leur-Bloem's purpose was to carry out a reorganisation that would qualify as 'merger by exchange of shares', in order to have the possibility of setting off any losses within the tax entity thus created. The tax authority denied this treatment on the grounds that the purpose would not be to establish a permanent single entity; as such an entity already existed, taking into account that the would-be merged companies had the same director and solé sharehokler. There was no business purpose in the operación, according to the tax auchorities. Leaving aside che very arguable conclusion that the ECJ may rule on a case that is strictly domestic/ ${ }^{8}$ the relevance of the case lays in the requisites for a reorganisation co benefit from the special tax regime.

In principie, the Court seems to admic che 'tax purpose', just as in Helvering the 'right' to minimise taxes was also accepced. Buc this is done in order to determine the scope of the Directive rules:

Tt must be observed first of all that it is clear from Article 2(d) and from the general scheme of the Directive that the common tax rules which it lays down, which cover different tax advantages, apply without distinction to all mergers, divísions, transfer of assets or exchanges of shares irrespective of the reasons, whether financial, economic or simply fiscal, for those operations [para. 35] ... Consequently, the fact that the acquiring company, within the meaning of Article 2(h) of the Directive, does not itself carry on a business or that the same natural person, who was the solé shareholder and director of the companies acquired, becomes the solé shareholder and director of che acquiring company does noc prevent the operacion from being treated as an exchange of shares within che meaning of Article 2(d) of the Directive' (para. 36).

The Court then admits the tax motivation as a valid economic reason.

Of course that admission is later subject to a number of nuances; Member States may, as authorised by the Directive, restrict the appíication of its tax benefits in the absence of valid economic motives, and they may thus stipulate 'thac che face chac chose operations were noc carried out for valid commercial reasons constitutes a presumption of tax evasión or tax avoidance' (para. 40). However, and here is where restrictions begin: 'in order to determine whether the planned operación has such an objective, che competent national authorities cannot confine themselves co applying predetermined general criteria but must subject each particular case to a general examination' (para. 41). The Court considers that 'the laying down of a general rule automatically excluding certain categories of operations from the tax advantage [...] would go further than is necessary for preventing such tax evasión or tax avoidance and would undermine the aim pursued by the Directive' (para. 44). The Court also makes it clear that the restricción does not only apply to the words of the provisión itself, but extends also to its interpretación by the domestic coures and tax authorities: 'this would also be the case if a rule of this kind were to be made subject to the mere possibility of the grane of a derogación, ac che discretion of the adminisrrative authority' (para. 44).

(4) As for the concept of valid commercial reasons, the Court is also extremely careful when analysing the actual factors that had been put forward in order to deny the tax benefits. The result is a considerable widening of the scope of such reasons:

'A merger or a restructuring carried out in the form of an exchange of shares involving a newiy-created holding company which does noc cherefore have any business may be regarded as having been carried out for valid commercial reasons. Similarly, such reasons may render necessary the legal restructuring of companies which already form an entity from the economic and financial point of view. Even if this may constitute evidence of tax evasión or tax avoidance, it is nevertheíess possible that a merger by exchange of shares with the aim of creating a specific structure for a limited period of time and not on a permanent basis may have valid commercial reasons' (para. 42, author's emphasis).

The Court seems to feel compelled to give an explanation of such a restrictive view:

'According to the first recital of its preamble, the aim of the Directive is to introduce tax rules which ate neutral from the point of view of competition in order to allow enterprises to adapt themselves to the requirements of the common market, to increase cheir productivity and to improve cheir competitive strength ac che internacional level. That same recital also stares thac mergers, divisions, transfers of assets and

\section{Notes}

Gtlbert v Commissioner, 248 F 2d 399, 411 (2d Cir 1957) A recorded and cióse origin of the business purpose test can actually be found in the 'subst.ince over form' doctrine, not exclusive of tax law; see further details at Nevermann, n 16 above, p 240

$7 s$ Seo in this regard: Caamaño Anido, Calderón Carrero and Martín Jiménez, n 51 above, p 415 
exchanges of shares concerning campantes of different Metnber States ought not to be hampered by restrictions, disaduantages or distortions arising in particular from the tax provisions of the Member States* (para. 45, author's emphasis).

In the end, what the Court says may not be so consistent with what the Court does: although its opinión seems to be to leave the door open for the establishment of anti-avoidance provisions, it nevertheless denies one that was feasibly a tax driven purpose (horizontal off-setting of losses). In my opinion, the fact that the Dutch tax law offered the possibility of benefiting from a tax-free reorganisation that will also allow for the horizontal off-setting of losses should not have been considered enough to act as a safe harbour rule that may exelude avoidance. ${ }^{79}$

In principie, the Court's interpretation is in line with its literal approach to anti-avoidance measures. Notwithstanding, in this case it may be arguable whether the interpretation of the Directive is actually consistent with its literal meaning at all, as in the Court's view, the mere existence of an economic reason seems to be enough, and it is not clear that this interpretation is even consistent with its objective, in that it does not seem to consider the purpose of the tax provisions establish in the Directive. ${ }^{80}$ That is probably the main difference with Heli/ering, where the courts departed from the tax provisions themselves.

Of course the first problem that appears vvhen analysing a given transaction or arrangement from the perspective of its business purpose is that it is very usual that a taxpayer enters a transaction having, as one of his objectives or even as one of the most important objectives, to minimise taxes. This is, however, not the object of anti-avoidance provisions or anti-avoidance judicial constructions. What should trigger them, in order to disregard the operation for the purpose of the tax benefit, is both that and the fact that the way taxes were minimised or avoided 'confliets with or defeats the evident intention of the Parliament'. ${ }^{81}$ That conflict will not ensue if the transaction can be regarded as protected, what will happen not only when it does not conflict with the said intention, but also when it has been encouraged by legislation. The problem is that the ECJ seems to attend only to this last element, what necessarily derives either from an excessive literalism in interpreting the tax benefits established in the Directives, or from a purpose oriented interpretation of such norms which departs only from the fundamental freedoms, thus disregarding the 'purpose' of the tax provisions themselves that seem to be regarded more as burdens than as norms per se.

In my view, the problem lies in the fact that the ECJ treats anti-avoidance measures as something located outside the provisión establishing the tax benefit - the Merger Directive in that case - instead of considering it a part of the correct interpretation of the norm itself, as we have argued earlier in this work. In Leur-Bloern the Court carnes out a very strict interpretation of s. 11 of the Directive, from which it follows that Member States cannot impose requirements that intend to counter or curb abuse that are not perfectly aligned with the said provisión. ${ }^{82}$

In the end, it is quite clear that when the national anti-avoidance provisión is a development of one that had been previously authorised or established in a Directive, the Court directly establishes the concept of tax avoidance, and when the anti-avoidance provisión has been established by the Member State in the first place, to the extent that it may be applied to EUtransactions, the ECJ subjeets them to a number of requirements that are not all that clear but that can be summarised in the requirement that any anti-avoidance measure must be proportionate to its objective and should have a minimal incidence in the transactions whatsoever, so that it may be declared void when it is feasible to imagine other, less restrictive, measures to the same end (Lasteyrie, 1CI, inter alia) $P$

\section{B. Soma remarks on the ECJ's concept of tax avoidance and its consequences for GAARs in Europe}

\section{The problem with the purported EU concept oí tax avoidance}

The Court has established a concept of tax avoidance, albeit roughly and in an indirect manner. ${ }^{84}$ The ECJ doctrine can only be understood bearing in mind that every element of tax avoidance legislation must be defined in accordance to the fundamental freedoms which, more often than not, entail that an arrangement carried out in the exercise of such freedoms sha 11 not be considered avoidance. Therefore, any-arrangement that purports to benefit from a better tax regime is in principie adequate when it has been entered into in the

\footnotetext{
Notes

As Weber, n 68 above, p 65, among ochéis, suggests

García Prats, see n 7 above, p 201

iFS, see $\mathrm{n} 4$ above, p 59-

Hoenjet, see n 66 above, p 212

Calderón Carrero and Martín Jiménez, see n 52 above, pp 82 and 83; Calderón Carrero, see n 68 above

Wolfgang Schón: 'Gestaltungsmibbrauch im curopáischen Sceuerrechc', Internationales Steuerrecht 1996, pp 11 and 12; Radler; Lausterer and Blumenberg: 'Tax abuse and EC law Does the general application of the Germán Anti-Abuse Rule under sección 42 of the Germán General Tax Act to Germán parcicipations in Irish 1FSC subsidiarles infringe Community law ?', EC Tax Review 1997, no 2, p 97; García Prats, see n 7 above, p 169
} 
exercise of a fundamental freedom. The freedoms often constitute a sort of 'saving clause' with regard to tax avoidance.

The limitation of anti-avoidance measures by the ECJ may be in many cases justified by the need to assure an adequate functioning of the fundamental freedoms. But this must be coherent with the limitation, and the rationalisation, of special low taxation regimes, as authorised by the Commission. The free competition model cannot function in the EU if the other derivation of the non-discrimination principie, the Aid of State regime, does not also opérate correctly. As inconsistent with the UE principies are the forms and arrangements that may abuse certain tax benefits, as may be the benefits themselves. Both must comply with the general EU principies. U. Paschen goes further and states that it should then necessarily follow that an arrangement that has been entered hito in order to benefit from a lower tax regime which does not comply with the fundamental freedoms, would qualify as tax avoidance. ${ }^{85}$ The idea is to purport a reasonable understanding of the possibility of tax competition, which is not by itself a right but only the natural consequence of the normal functioning of the EU fundamental freedoms, just as the 'right' to save taxes is merely the natural consequence of the possibility of choosing different legal forms or ways to carry out a business, as explained above. However, anti-avoidance rules and the regime of the Aid of State are so different in their basis as in their requisites and consequences that the said reasoning can hardly be shared.

In the present moment, the interpretation of the Court may give place to a number of dissonances with the common knowledge of tax avoidance. In the Court's view, only those arrangements that can be considered artificial may be disregarded for tax purposes. Furthermore, artificiality is defined in such strict terms that, in the limit, it presents certain similaríties with the sham. Because the question was not vvhether Ms. Leur-Bloem had actually carried out a reorganisation or not; for she obviously had, at least taken from the perspective of the commercial laws regulating them. Viewed from that perspective, it was not an artificial arrangement. The question was rather whether she had a right to a tax-free reorganisation. In order to assess this last element one cannot ignore the tax norms. The interpretation must take into account the relevant tax provisions, not just the commercial laws and, for that matter, the fundamental freedoms. It cannot be carried out outside the boundaries of the tax norms, for then not just the door for tax planning, but to sheer tax avoidance will be ajar.

In the end, what purposive interpretation of tax provisions actually means is that tax law must detach itself from prívate law. The opposite view invariably leads to a breeding grouncl for tax avoidance. As I ha ve pointed out earlier on in this article, the stricter, and the less autonomous, the interpretation of tax norms, the easier it will be to bring about successful tax avoidance schemes.

The problem then, is that the ECJ is interpreting tax law, and of course anti-avoidance provisions, from the perspective of the fundamental freedoms, which mayor may not coincide with the 'traditional' tax principies. Thus, while the principie of non-discrimination which lies at the origin of the four fundamental freedoms, has a great área of coincidence with the equality principie in taxation, that is not the case for other principies, that necessarily require uneven treatments, such as the ability to pay principie. In that regard, the ECJ theory on tax avoidance may genérate inequalities, in the sense of preventing a correct assignment of the tax burdens. ${ }^{86}$ In this regard, it is pertinent to point out that fiscal control measures may also serve the purpose of assuring an adequate distribution of the tax burden.

Furthermore, at the same time that the ECJ limits the concept of tax avoidance, it may be incentivizing the use of GAARs instead of specific anti-avoidance measures by Member States. To a certain extent, the attack to the specific anti-avoidance measures should be welcomed, at least in that they are deemed to genérate a number of perverse side effects. ${ }^{87}$

But the ECJ case law also has a clear incidence in the GAARs, as it forces their re-interpretation when applied to the EU context. In order to counter avoidance, Member States may develop doctrines preventing the abuse of fundamental freedoms, which shall of course be subject to further examination by the Court, or they may apply their national legislation against tax avoidance (i.e. Art. 15 of the LGT, s. 42.1 of the AO, etc.), bearing in mind that it should at the same time comply with the requisites of the general interest exemptions. ${ }^{88}$

A good example of how GAARs can be applied to EU situations without a problem is the reasoning of the BFH in the in the Duhlin Docks cases. ${ }^{89}$ The facts show a typical case of income outsourcing undertaken by a Germán society towards another capital holding Corporation (Kapitalanlagegeseílschaft) domiciled in

\footnotetext{
Notes

Pasclien, see n 6 above, p 220

\& García Prats, see n 7 above, p 176

8 Such as creating 'road maps' for would-be cax avoiders, increasing che complexity of cax systems and others pointed out by che Cárter Commission, 1966, pp 554556; Nevermann, see n 16 above, p 82; 1FS, see n 4 above, pp 4 and 5; Gammie, see n 74 above, p 194

69 Calderón Carrero and Martín Jiménez, see n 50 above, p 64

s9 Germán investment in the Dublin Docks área has given place to a large number of BFH decisión» The two 'correct' decisions, that establish the main guidelines to interpret the s 42 of the AO, with regard to the Ausbensteuergesetzt and the EU law are the decisions of 19 January 2000, (BStBl 11 2001, 222) and of 25 February 2004 i 1 R 42/02) Only the latter exprcssly refers to EU law and the fact that che Irish arca had an express authorisation by the Commission to implement the especially low tax cegime (see particularly para 24) Both decisions can be viewed at www bundesfinanzhof de
} 
Dublin and located in the Dublin-Docks, that is the International Finance and Service Centre (IFSC), at the border Custom House Docks Área that benefits of a very advantageous tax regime, which includes among its advantages a 10 per cent tax rate in Corporation income tax, as approved by the EU. Clearly, the Germán GAAR (s. 42 of the AO) could only be appiicable taking into account the existing Irish state aid that had been previously authorised by the Commission, which conformed a sort of protected transaction. ${ }^{90}$ This is vvhat the BFH has stated after much controversy and decisions holding different views. ${ }^{91}$

As for the Spanish GAAR, in principie Art.15 of the LGT seems to comply with the ECJ. ${ }^{92}$ At least in theory, for we must also take into account the interpretation carried out by the Spanish tax authorities. And here is where problems may begin. Apart from the problems deriving from its relationship with international treaties, which will not be discussed here, ${ }^{93}$ the decisions are vague, erratic and not all that predictable. ${ }^{94}$

In short, to the extent that this may bring about a narrowing in the scope of the Member States' GAARs, and bearing in mind that such provisions are meant to protect their tax systems, the ECJ case law falls on the core of the design of tax systems, especially taking into account that, at the present raoment, virtually every EU country has anti-avoidance legislation or case law. ${ }^{95}$ Of course it may be true that the absence of common anti-abuse rules may lead to a distortion of the Common Market. ${ }^{96}$ The final problem is who is to define the common rule, or for that matter, a common interpretation to what abuse or avoidance really is.

\section{The problem with neutral (sic) tax provisions}

Neutralíty has often been mentioned as the objective of tax measures in the EU. To U. Paschen, it would be the only criterion suitable to establish a uniform inter- pretation of anti-avoidance measures in the domestic, European and international arenas. ${ }^{97}$ The problem with neutrality in taxation is that it is not alvvays clear whether it even exists. Every tax brings about all kinds of effects quite apart from the obtaining of revenues. ${ }^{98}$ Of course in some cases the tax norms mean to bring about other effects, such as influencing the behaviour of the taxpayer. In that case there is an intended neutrality. ${ }^{99}$ However, more often than not, what some refer to as neutrality is actually the construction and interpretation of tax measures following the acts or arrangements as defined in prívate law.

This is why neutrality cannot easily be employed as a criterion without being misleading, at least when referred to tax statutes. The criterion must consist of whether or not the arrangement compites with the norm, which necessarily takes us back to the problem of purposive interpretation. According to the ECJ interpretation, the Merger Directive may function as a sort of 'safe harbour', in the sense that transactions carried out under its scope are 'protected transactions' with regard to tax avoidance provisions. The reasoning seems to imply that, precisely because the Directive contains a clear incentive to merge, in order to facilitate commerce, it is not possible to deny the tax benefit on the exclusive grounds that the taxpayer actually did merge for tax reasons. ${ }^{100}$ In this case, the (tax) norm may be implicitly asking the taxpayer to do something for tax reasons. If that is the case, it is obvious that one cannot deny the benefit to the taxpayer on the grounds that it was a tax driven transaction, for that is precisely one of the elements that has been taken into account by the norm. ${ }^{101}$ In the end, what explains many ECJ decisions is not primarily that the anti-abuse provisión or equivalent goes against the fundamental freedom - although that might be the consequence - but its inconsistency with the ends of the tax regime (benefits, exemptions) as established in the Directive. The anti-abuse provisión

\footnotetext{
Notes

Rádler; Lausterer and Blumenberg, sce n 84 above, p 99

\% These cases wcnt so far as to cause a tax reform Because in the first of the cases the BFH liad decided not to apply the general anti-avoidance rule, on the grounds that the AStG prevailed, as it was considered as a special anti-avoidance provisión, the tax authorities put forward, and obtained, a change in the AO, by introducing para 2 in $\mathrm{s} 42$, which states that the GAAR set in para 1 will be applicable except when its application is expressly ruled out by any other law This provisión, which constitutes a weird exception to the classicai rule of lex specialis derogat lex generalis has been welcomed with an almost unanimous critic, on the grounds that it is logically absurd, as well as useless The reform, triggered by the above cited BFH case, entered into forcé shortly after, on 23 December 2001 In the end, the reform was a desperate attempt to make s 421 of the AO applicable at any rate, especially in the European context There are many interesting aspeets to this case which would requirc a different study Not surprisingly, plenty of ink has flowed regarding these cases, see inter alia: Bauschatz, 2002, p 334; Hoffmann, 1996, p 6588; Ruiz Almendral and Seitz, no 7 above, p 33

\% Of the same opinión is Vega Borrego, n 57 above, p 372, footnote 1112, with reference to the former spanish GAAR, which however shared the essential elements with the present one, as I maintain with Georg Seitz, n 7 above

4) See in this regard Martín Jiménez, n 48 above

s4 See, inter alta, Ruiz Almendral and Seitz, n 7 above; Ruiz Almendral and Zornoza Pérez, n 39 above

*5 Paschen, see n 6 above, p 198; Ruiz Almendral and Seitz, n 7 above

* Albert J Rádler: 'Do National Anti-Abuse Clauses Distort the Internal Market?', European Taxation 1994, n 9, p 313

Paschen, sce n 6 above, p 208

\%F Fritz Neumark: Grundsaeze gerechter und okonomisch rationaler Steuerpolitik (J C B Mohr (Paul Siebeck), Tiibingen, 1970), p 261; Birle, see n 6 above, p 8

“7 Klaus Vogel: 'Die Absichtung vori Rechtsfolgen im Steuerrecht', Steuer und Wirtschaft 1997, no 2, pp 97 and 98 ; Tipke, see n 6 above, p 122

Ino García Prats, see n 7 above, p 175

We See this idea at the following BFH decisión: 9 November 2000, BStBl II 2001, 101, 102 See also in this regard: Falcón and Telia, see n 4 above, p 8; IFS, see n 4 above, pp 43 and 44; Georg Crezelius: 'Das Argumentationsmuster des sog Gesamtplans', Finanz-Rundschau, 8 June 2003, no 11, pp 537 and 541
} 
does not comply with the purpose of the EU norra, which is of course interpretad in line with the freedoms. This should not happen with a GAAR, as it leaves a broader leeway to be interpretad by the tax authorities, who should bear in mínd all the pertinent legislation, especially including, of course, the tax exemptions that may have been strived for.

\section{A new approach? The opinión of Advócate Genera! Mr. Miguel Polares Maduro on VAT avoidance}

The recent Opinión of Advócate General Miguel Poiares Maduro sheds new light on the problem of tax avoidance in the European arena. Although the general tone of the Advócate is that of continuity with the previous ECJ case law, the fact is that it represents a qualitative turn in its general definition of avoidance as I have explained in previous pages. Should the Court finally accept Mr. Poiares' proposal, it will bring about a much more reasonable approach to the problem of tax avoidance, at least in the author's view. It is then especially pertinent to dedícate extensive attention here to this Opinión, as it constitutes a turn in the tax avoidance doctrine that could be perfectly extrapolated to cases involving other taxes.

The Opinión, delivered on 7 April 2005, regards the accumulated cases C-255/02 (Halifax $v$ Cornmissioners of Customs); C-419/02 [BUFA Hospitals v Cornmissioners of Customs and Excise) and C-223/03 (University of Huddersfield Higher Education Corporation $v$ Cornmissioners of Customs and Excise). The three cases refer to transactions entered hito for the purpose of gaining a tax advantage in terms of a right to deduct input VAT. ${ }^{102}$ In a nutshell, the Court is asked, first, to determine whether transactions carried out with the solé purpose of enabling input tax to be recovered may constitute an 'economic activity' within the meaning of s. 4.2 of the Sixth Directive. Secondly, to determine whether the doctrine of 'abuse ofrights' can be applied in the field of valué added tax, in order to disallow the claims to deduct this tax. ${ }^{103}$ As can easily be inferred from the following lines, the Opinión is not cxclusively applicable to VAT.

An activity can be considered an economic activity in the VAT sense even if it is carried out for the solé purpose of avoiding the tax. As we have seen in previous paragraphs, there are two ideal ways of dealing with avoidance cases, by interpreting and recharacterizing the act or arrangcment, leaving it in or out the scope of the norm, or by accepting it fLilly but disregarding the tax benefits that it intends to obtain. These two possibilities were present in these VAT cases. The Advócate General opts for the second; to admit that it was an economic activity, as it does not lose its nature even when its main purpose was to avoid or defer the payment of the tax (para. 46), and then allow, as we will see, for a disregarding of the consequences.

'It is true - the Opinión goes - that the transactions at issue in the present cases appear to be mere instruments or indirect dealings for the ímplementation of complex tax avoidance schemes. Tax avoidance, however, remains, in any case, an activity that is not inherently linked to the various business activities objectively carried out for consideration in each of the particular transactions at issue. The tax avoidance purpose is therefore an external circumstance that does not change the inherent and objective nature of each of those transactions' (para. 47).

This is perfectly coherent with the general definition of tax avoidance dealt with in the first part of this study. Tax avoidance presupposes the existenee of valid commercial transactions. Actually, those transactions must bring about its economic effeets in order to obtain the desired effect in the form of a tax benefit. The arrangement or act is perfectly valid from the prívate law perspective. The opposite view, not only would make tax avoidance an impossibility, but as Mr. Poiares puts it, would be against the objective nature of the notion of 'economic activity', 'which constitutes a fundamental feature of the VAT system, imposed by the principie of legal certainty, and should not be lelt to depend on the intentions of the traders involved' (para. 51). In short, 'the services and goods were effectively transferred in return for consideration, albeit as part of an operation that had been carefully orchestrated in order to créate a right to recover input tax' (para. 50).

Furthermore, this is also the only possibie interpretation consistent with the scope and application or EU law, as 'the need to prevent tax evasión or avoidance cannot therefore justify the adoption of national measures derogating from the directive otherwise than under the procedure provided for in Art. 27 \{Commission/Frunce, para. 22) or rather, 'only derogations that are proportionate and necessary to achieve the aims expressly mentioned in Article 27 [of

\section{Notes}

1.2 1 will not go into all detaiis of the cases, which are very well explained in the Opinión Suffice it to say here that all of the three cases refer to schemes built in order to fully recover the whole of the input VAT on certain services and goods that, but for the schemes, would not have been possibie, as their main activities were exempt

105 The question, as formulated in the Halifax, is the following

'(I) (a) In the relevant circumstances, do transactions:

(i) effected by each participator with the intention solely of obtaining a tax advantage and

(ii) which have no independent business purpose

qualify for VAT purposes as supplies made by or to the participators in the course of their economic activities?

(2) Docs the doctrine of abuse of rights as developed by the Court opérate to disallow the Appeliants their elaims for recovery of or relief for input tax arising from the implementation of the relevant transactions?" 
the Directive] are authorised' (para. 77); 'the prohibition of abuse of Community law, seen as a principie of interpretation, does not give rise to derogations from the provisions of the Sixth Directive'; 'the operation of this principie of interpretation does not entail the result that the economic activities carried on ought to be disregarded for VAT purposes or left outside the scope of the Sixth Directive. An interpretation of the Sixth Directive according to this principie cannot but have the most obvious consequence to be expected in the context of legal interpretation: that the right is not in fact conferred, contrary to the literal meaning of the legal provision. If this interpretation entails any kind of derogation, it will be only from the text of the rule, not from the rule itself, which comprises more than its literal element' (author's ernphasis, para. 78).

In this case, the correct way to counter tax avoidance is not to limit the scope of the tax rules, but to carry out a correct interpretation of the tax statutes and nontis. The Advócate dedicates special attention to explain why the first approach, a limitación of the scope of the VAT rules for avoidance transactions, would not only be ineffective, but would also incur in a breach of the necessary legal certainty, as required by the rule of law. Furthermore, it would pose the problem of how to reconstruct the operations, should they be left outside the scope of the VAT. In the words of the Advócate General:

'when one disregards tax avoidance transactions by leaving them outside the scope of the VAT system, it will be necessary to reconstruct the chain of supplies to redefine the identity of the recipients of those supplies that remain subject to VAT. Most Sikely the recipients of such supplies will not be those designated by the contracts or invoices relating to the disregarded transactions. This reconstruction poses serious problems ... First, it assumes the existence of one normal way to carry on ... but there is a risk that it might be a mere product of the imagination, because there is in principie no single normal way to conduct an economic activity ... Secondly, it disregards germine transfers of property, or supplies of services made in return for economic consideration, to focus instead on the overall result of the operation' (paras. 54-56).

This way of arguing acknowledges that the most effective solution to counter a scheme designed in order to obtain certain tax benefits, is to deny the benefits themselves, rather than leaving the whole scheme outside the system. This is exactly the approach followed by most GAARs and anti-avoidance judicial doctrines, as I have explained above.

The abuse of rights: the (long and winding) road to recognise fraus legis in taxation in its own right. The Advocate's answer to the question of whether or not the notion of 'abuse of rights', previously recognised by the Court in other áreas of Community law, may also be applícable in the field of VAT is specially interesting, as it becomes plain that the ECJ has indeed developed a doctrine which is perfectly in line with all anti-avoidance provisions and judicial doctrines. However, such a doctrine has not, as we have seen above, been normally applied to taxation issues or, specifically, to cases involving tax avoidance schemes. On the contrary, anti-avoidance measures seem to have been largely regarded more as burdens standing in the way to EU market integration than as measures protecting the tax systems themselves.

As the Advócate summarises, the notion of abuse in the case law of the ECJ has made it clear that: 'the improper circumvention of a Member State's rules by the exploitation of [the fundamental] freedoms is not permissible', ${ }^{104}$ 'benefits cannot be acquired by way of abuse or fraudulent conduct', that 'if it could be shown that the importation and re-exportation of the cheese were not realised as bona fide commercial transactions, but only in order wrongfully to benefit from the grant of monetary compensatory amounts' the payment would not be due, ${ }^{105}$ and that, at any rate, 'a iMember State is entitled to take measures designed to prevent certain of its nationals from attempting, under the cover of the rights created by the Treaty, improperly to circumvent their national legislation or to prevent individuáis from improperly or fraudulently taking advantage of the provisions of Community law'. 106

Although the notion of abuse has been basically analysed regarding Community law provisions (that are abusively invoked in order to evade national law or that are abusively relied upon in order to gain advantages in a manner that conflicts with the purposes and aims of those same provisions (para. $62)$ ), the existing case law allows the extraction of a general principie of Community law, which cannot then 'be relied on for abusive or fraudulent ends'.

Regarding moving towards a clear recognition of GAARs, the Advócate goes on to extract the pertinent consequences of the aforementioned notion of tax abuse with regard to tax avoidance. Here, the first paragraph is very cautious. Mr. Poiares acknowledges the fact that the ECJ has not precisely been widely endorsing the tax avoidance doctrine, but he does that in very 'diplomatic' terms, by stating that 'the Court attempts to strike a cautious balance between leaving it to the national courts to assess the abuse in accordance with their own relevant national rules and ensuring that that assessment does not prejudice the full effect and uniform application of the Community law

\section{Notes}

${ }^{104}$ Among other, as quoted in the Opinión, see: Case 33/74 Van Binsbergen \{para 13); Case C-148/91 Verónica, para 12; C-23/93 TV10, para 21

${ }_{10 ! 5}$ Genera/ Mi/fe Producís, C-8/92, para 21

${ }^{106}$ C-212/97 Centros, para 24 
Tax Avoidance and the European Court of Justice: What is at Stake for European General Anti-Avoidance Rules?

provisions allegedly relied upon in an abusive manner'. Consequently, it continúes, 'the Court has developed the parameter according to which that assessment is to he made at national level. First, the assessment of the abuse must be based on objective evidence. Second, and most importantly, it must be made in conformity with the purpose and objectives of the provision of Community law allegedly relied upon in an abusive way' (para. 64).

Once this sort of warning (or maybe apology), has been made, the Opinión goes on to demónstrate, and acknowledge, for the salce of the accumulated cases, that the general anti-abuse case law is perfectly applicable to the contended VAT cases. The Opinion departs from Emsland Stdrke (C-110/99), a case regarding export rights, ${ }^{107}$ to establish that the following.

* In order to determine the existence of an abuse, a purposive interpretation of the pertinent norms must be undertaken - the assessment of the abuse is based on whether the right claimed is consonant with the purposes of the rules that formally give rise to it' (para. 67), thus admitting that 'a decisive factor in affirming the existence of an abuse is the teleological scope of the Community rules invoked' (para. 68)\}.

\# Such a track of thought should inform the interpretation of all Community law - this notion of abuse operates as a principie governing the interpretation of Community law' (para. 68).

(B) The notion of abuse is purely objective - thus: 'artificiality should not be based on an assessment of the subjective intentions of those claiming the Community right. The artificial nature of certain events or transactions must certainly be determined on the basis of a set of objective circumstances verified in each individual case' (para. 69), and: 'the intentions of the parties to improperly obtain an advantage from Community law are merely inferable from the artificial character of the situation to be assessed in the light of a set of objective circumstances' (para. 70).

- Not only to determine the existence of abuse, also in order to counter abuse, a purposive interpretation of the norm must follow: 'Provided that those objective circumstances are founcl to exist one must conclude that a person who relies upon the literal meaning of a Community law provisión to claim a right that runs counter to its purposes does not deserve to have that right upheld'. In such circumstances 'the legal provisión at issue must be interpreted, contrary to its literal meaning, as actually not conferring the right ${ }^{108}$ (para. 70, author's emphasis).

Finally, the Advócate General transfers all this reasoning to the problem of tax avoidance in the VAT. Departing from a general assumption that 'the common system of VAT is likewise not immune to the risk, inherent in every legal system, that actions may be taken which, despite formally complying with a legal provisión, amount to abusive exploitation of the possibilities left open by that provisión, contrary to its purposes and objectives' (para. 72), which of course can easily be made extensible to any other tax. Mr. Peñares dedicares special attention to justify why this abuse doctrine should be appliecl to VAT:

'It is difficult, therefore, to conceive the common system of VAT as a sort of abuse-free domain within the Community legal system where that principie would not have to be respected. There is no reason why such a general principie of Community law should have to depend, in this área, on an express statement by the legislature that the provisions of VAT directives also do not escape the rule, consistently upheld by the Court, that no provisión of Community law can be formally relied upon to secure advantages manifestly contrary to its purposes and objectives. Such a rule, conceived as a principie of interpretation, constitutes an indispensable safety-va.lve for protecting the aims of all provisions of Community law against a formalistic application of thern based solely on their plain meaning'l (para. 73, author's emphasis).

After reading this, one can only wonder: why devote so many words to something so obvious, namely, that law should not be abused? The only feasible answer is that the Opinion is implicitly admitting that the ECJ approach on tax avoidance has indeed been quite formalistic. Only that. can explain why so many times in the subsequent paragraphs the same idea is repeated. ${ }^{109}$

Member States do not need to be authorised by the

\section{Notes}

Specifically, as described in the Opinión (para 65), 'the Court was asked whcthcr an exponer could be divested of irs right to an exporr refund despite che fact chat the formal conditions for the grant of the refund were met in accordance with the relevant provisions of Commission Regulación (EEC) No 2730/79 of 29 November 1979 laying down common detailcd rules for the application of the systems of export refunds on agricultural produets, In essence, the goods at issue had been the subiect of a U-turn seríeme under which they were exported and released for home use in a third country but were immediately re-imported into the Community unaltered and by the same means of transport'

106 Author's einphasis

68 'The idea that this notion is equally applicable in the sphere of VAT is entirely consisten! with the posición recently adopted by the Court in Gemeente Leusden according to which 'prevención of possible tax evasión, avoidance or abuse are objectives which are recognised and positively encouraged by che Sixth Directive' (para 73) 'To the exrent to which that principie is conceived as a general principie of interpretación it does not require express Icgislacivc recognition by the Community legislature to render it applicable to the provisions of the Sixth Directive From che mere absence of a provisión in the Sixth Directive cxprcssly setting Community legislature to render it applicable to the provisions of the Sixth Directive From che mere absence of a provision in the Sixth Directive cxprcssly setting
out a principie of incerpretation whereby abuses are proscribed - and the same could apply, for example, to the principies of legal cercainry or the protection of legitímate expectations, as che Irish Government observed at the hearíng- we cannot therefore draw the conclusión that the Community legislature intended to exelude that principie from che Sixth Directive Conversely, even if there were a provisión in the Sixth Directive cxprcssly stating that principie, it could be regarded, as the Commission pointed out, as a mere declaración or codification of an existing general principie' (para 74) 
Directive to apply their GAARs or judicial doctrines; the Advócate General expressly recognises the application of GAARs, and for that matter, judicial antiavoidance doctrines, to VAT, without it being necessary that Member States actually establish appropriate anti-avoidance provisions following Art. 27 of the Sixth Directive, for if that were the case, 'the Common system of VAT would become a peculiar legal domain where virtually any opportunistic behaviour by taxable persons relying on the literal meaning of its provisions to improperly gain tax advantages against the tax authorities would have to be tolerated unless the Member States liad previously adopted legislative measures forbidding such behaviour' (para. 75).

'I see no reason, in short, why the VAT rules should not be interpreted in accordance with the general principie of the prohibition of abuse of Community law. It is true that tax law is frequently dominated by legititnate concerns about legal certainty, deriving, in particular, from the need to guarantee the predictability of the Financial burden imposed on taxpayers and the principie of no taxation without representation. However, a comparative analysis of the Member States' legal rules is sufficient to make it clear that such concerns do not exelude the use of certain general provisions and indeterminate concepts in the realm of tax law to prevent illegitimate tax avoidance. Legal certainty must be balanced against other valúes of the legal system. Tax law should not become a sort of legal "wild-west" in vvhich virtually every sort of opportunistic behaviour has to be tolerated so long as it conforms with a strict formalistic interpretation of the relevant tax provisions and the legislature has not expressly taken measures to prevent such behaviour' (para. 76).

In a footnote, the Advócate General expressly mentions most existing anti-avoidance measures in Member States, including the Spanish s. 15 of the LGT.

An interpretation consistent with EU law does not necessarily have to limit the scope and application of anti-avoidance measures: 'Provided that those Community law provisions purport to achieve certain aims and results, the domestic rules irnpíementing them must be interpreted and applied by national authorities in accordance with those purposes' (para. 80).

The construction of the Community law notion of abuse must comply with the principies of legal certainty and of the protection of legitímate expectations of taxpayers: the Advócate General is familiar with the ongoing reproaches that GAARs are not certain enough to meet the strictfer?) standards of the rule of law in the tax field, so he soothingly states that: 'the objective analysis of the prohibition of abuse has to be balanced against the principies of legal certainty and protection of legitímate expectations that also form part oF the Community legal system. From those principies it Follows that taxpayers must be entitled to know in advance what their tax position will be and, For that purpose, to rely on the plain meaning of the words oF the VAT legislation' (para. 83).
By the same token, the Advócate General also seems to Feel compelled to tranquilise taxpayers, and goes on to acknowledge the ECJ rules that 'diere is no legal obligation to run a business in such a way as to maximise tax revenue For the State. The basic principie is that of the freedom to opt for the least taxed route to conduct business in order to minimise costs', but of course does not fail to stress the fundamental point (that makes the 'right' not to be a right after all, as shown in previous pages), which is that 'such freedom of choice exists only within the scope of the legal possibilities provided For by the VAT regime. The normative goal of the principie oF prohibition of abuse within the VAT system is precisely that of defining the realm oF choices that the common VAT rules have leFt open to taxable persons. Such a definition must. take into account the principies of legal certainty and of the protection of taxpayers' legitímate expectations' (para. 84).

Once the two main fears of taxpayers before GAARs - that they are not too vague and that they respect the possibility of choosing the road less taxes have been dealt with 'by virtue of those principies, the scope of the Community law interpretative principie prohibiting abuse of the VAT rules must be defined in such a way as not to affect legitímate trade' (para. 85), the Opinión finally goes on to admit the full applicability of tax avoidance doctrines in VAT. In doing this, the Opinión fully admits the main elements of GAARs as described in the first part of this article.

Starting by the definition, prohibition of abuse means that:

'the right claimed by a taxable person is excluded only when the relevant economic activity carried out has no other objective explanation than to créate that claim against the tax authorities and recognition of the right would conflict with the purposes and results envisaged by the relevant provisions of the common system oF VAT. Economic activity oF that kind, even if not unlawful, deserves no protection from the Community law principies of legal certainty and protection of legitímate expectations because its only likely purpose is that of subverting the aims of the legal system itselF' (para. 85).

There are two elements to the notion oF abuse that must be present at the same time (paras. 86-87): the First is only Formally a subjective element, as it must be objectively determined with regard to the purpose of the activities (not the motive of the taxpayers), and which will depart From the 'absence of any other economic justiFication For the activity than that of creating a tax advantage'. And the second is oF teleological nature, 'whereby the purpose and objectives of the Community rules allegedly being abused are compared with the purpose and results achieved by the activity at issue'.

'This second element is important', so the Opinión goes, 'not only because it pro vides the standard upon which the purpose and results oF the activity in question are to be assessed. It also provides a saFeguard For those 
instáhces where the solé purpose of the activity might be to diminish tax liability but where that parpóse is actually a result of a choice between different tax regimes that the Community legislature intended to leave open. Therefore, where there is no contradiction between recognition of the claim made by the taxable person and the aims and results pursued by the legal provisión invoked, no abuse can be asserted.'

The Opinión then fully assesses the problem with protected transactions. Finally, as savings clause, there will be no tax avoidance 'where the economic activity carried out may have some explanation other than the mere attainment of tax advantages against tax authoriti.es' (para. 88).

The conclusion is that the taxable persons, according to the purposes of the VAT system of deduction just described, should not be able to deduce or recover input VAT except on a limited proportion of their inputs, have put into effect schemes that have enabled them to circumvent that result and recover input VAT in full. But, this must be established by the national courts (paras. 93-96).

\section{A final word}

This recent Opinión is perfectly in une with the common knowledge of tax avoidance that has been examined in this article. This should be welcomed, for at the present moment the ECJ interpretation on tax avoidance may be excessively strict. The ECJ has indeed tried to protect the fiscal interest of the Member States, but it has also carried out an interpretation that primarily promotes the realisation of the fundamental freedoms, sometimes, in this author's view, at the expense of accomplishing the very legitímate objectives sought for by anti-avoidance legislation. In the end, however, the Court may be putting in jeopardy the very same thing that it claims to protect: a coherent and functioning common market. Not only are taxes 'what we pay for civilized societyl as judge Holmes put it, ${ }^{110}$ but the whole idea that taxes should 'respect', not tamper with, not. hinder, not stand in the way, not be a burden etc. to the normal functioning of a market might be a fiction at best of times, as it departs from a reality that has been to some extent invented. As the very suggcstive and comprehensive work of Liam Murphy and Thomas Nagel \{The Myth of Ownership Taxes and Justice. London, OUP, 2002) demonstrates, taxes are and indissoluble part of the market economy as we know it, are therefore intrinsic, never external, to its functioning.
Clearly, this is not exclusive of anti-avoidance measures. In the end, in the words of F. Vanistendael, tax sovereignty 'is limited to the extent that it restriets the basic economic freedoms, ... Member States still retain their fundamental right of their tax reverme, though not the exact shape and form in which their income taxes are imposed on their taxpayers. Member States should learn to live with this phenomenon and if they want to do something about it, they better agree to legislare at the European level'. ${ }^{11}$ Not only EU integration, but the growing globalisation is increasingly changing and transforming the tax systems as we know them. At the present moment, all Member States' tax law in the EU finds itself at the crossroads between globalisation, the different legal forms ín civil or privare law, and the fundamental freedoms. ${ }^{112}$

\section{References}

Cárter Commission (1966). Report ofthe Royal Commission on Taxation, Vol. 3. Ottawa: Queen's Printer. Canadá.

Avery Jones, John F. (1983): 'Nothing either good or bad, but thinking makes it so - the mental element in antiavoidance legislation (I)'. British Tax Review, n. 9.

Avery Jones, John F., Ward, David A., et al. (1985): The Business purpose tesr and abuse of rights'. British Tax Review, n. 2.

Informe LGT. (2001): Comisión para el estudio y propuesta de medidas para la reforma de la Ley General Tributaria (Nombrada por Resolución de la Secretaría de Estado de Hacienda de 15 de junio de 2000).

Arnold, Brian (1995): The Canadian Anti-Avoidance Rule'. British Tax Review, n. 6.

Avi-Yonah, R, (2000): 'Globalisation, tax competition, and the fiscal crisis of the Welfare State', Harvard Law Review, vol.113, no. 7, 2000, pp.1575 y ss.

Baker, Philip (2002): 'Changing the Norm on Cross-border Enforcement of Tax Debts', Intertax, vol.30, no. 6-7, 2002.

Barquero Estevan, Juan María (2002): La función del tributo en el Estado Social y Democrático de Derecho. Madrid: Centro de Estudios Constitucionales.

Caarnaño Anido, Miguel Ángel; Calderón Carrero, José Manuel (2000): 'La erosión de las medidas de control fiscal del Estado de residencia: una reflexión al hilo de la jurisprudencia comunitaria, en el caso ICV. Revista de Contabilidad y Tributación, n. 207.

Caarnaño Anido, Miguel Ángel; Calderón Carrero, José Manuel (2002): 'Globalización Económica y Poder Tributario: ¿Hacia un nuevo Derecho Tributario?', CivitasREDF, no, 114,2002.

Calderón Carrero, José Manuel (2005a): 'European Transfer Pricing Trends at the Crossroads: Caught between

1:2 As the comprehensive study by Schón, n 63 above, p 58 shows Of course diere are other elements present at the same crossroad, that cannot be dealt with here with regard to transfer pricing, see: Calderón, n 57 above and also Calderón: 'European Transfer Pricing Trends at the Crossroads: Caught between Globalisation, Tax Competition and EC Law', Intertax 2005, vol 33, especially p 110; with regard to Treaty shopping provisions, see: Vega Borrego, n 57 above Finally, for the changes that this has entailed, inter alia, with regard to the 'revenue rule', see Philip Baker: 'Changing the Norm on Cross-border Enforcement of Tax Debts', Intertax 2002, vol 30, nos 6-7, p 216
} 
Globalization, Tax Competition and EC Law'. Intertax, vol. 33 .

Calderón Carrero, José Manuel (2005b): 'A Post-Denkavit Revievv of the Anti-Directive Shopping Rules in Spain: comments on a case involving US and Dutch Parent companies'. Tax Notes International (forthcoming).

Consejo de Estado (2003: Dictamen sobre el Anteproyecto de Ley General Tributaria. Número de expediente: 1403/ 2003 (HACIENDA), date: 22/5/2003. [quoted as: Consejo de Estado 2003.]

Cooper, Graeme S. (2001): 'International experience with general anti-avoidance rules'. Southern Methodist Vniversity Law Review, n. 83.

Crezelius, Georg (2003): 'Das Argumentationsmuster des sog, Gesamtplans', Finanz-Rundschau (FR), n. 11, de 08.06.2003.

Engisch, Kari (1975): Einfiihrung in das juristische Denken. Berlin: Verlag W. Kohlhammer.

Falcón Y Telia, Ramón (1995a): 'El fraude a la Ley tributaria como un mecanismo para gravar determinadas economías de opción (I): su radical diferencia con los supuestos previstos en el art. 6 C.C. Quincena Fiscal, n. 17.

Falcón Y Telia, Ramón (1995b): 'El fraude a la Ley tributaria como un mecanismo para gravar determinadas economías de opción (II): límites a la utilización de esta figura'. Quincena Fiscal, n. 18

Falcón Y Telia, Ramón (1999): 'El delito fiscal como ley penal en blanco: la necesidad de tener en cuenta todas las normas tributarias que afectan a la exigibilidad jurídica de una determinada conducta del contribuyente'. Quincena Fiscal, n. 10

Falcón Y Telia, Ramón (2002): 'El expediente especial de fraude de ley: un procedimiento que no existe, pero se aplica'. Quincena Fiscal, n. 21.

Ferreiro Lapatza, Juan José (1976): 'El objeto del tributo'. Revista Española de Derecho Financiero (Civitas), núm. 10.

Ferreiro Lapatza, Juan José (2001): 'Economía de opción, fraude de ley, sanciones y delito fiscal'. Quincena Fiscal, no. 8

Gammie, Makolrn (1997): 'Tax Avoidance and the Rule of Law: a perspective from the United Kingdom'. at AA.VV. (Ed. Graeme S. Cooper): Tax Avoidance and the Rule of Law. Arnsterdam: International Burean of Fiscal Documentaron.

Gustafson, Charles H. (1997): 'The politics and practicalities of checking tax avoidance in the United States'. En: AA.VV. (Ed. Graeme S. Cooper): Tax Avoidance and the Rule of Law. Arnsterdam: International Burean of Fiscal Documentation.

Heuermann, Bernd (2003): 'Vermieten ais angemessenes Gestalten'. Beetriebs-Berater, pp. 1465 y ss.

Hinnekens, Luc (1999): 'Uncertainties in the Interpretation of the General Anti-Avoidance Statute'. European Taxation, September.

IFS -The Institute for Fiscal Studies- (1997) Tax Avoidance A report by the Tax Law Review Committee. Novembcr (citado como IFS: 1997).

Kleer, Maurice de (1996): 'Towards a European Anti-Abuse Doctrine in Direct Taxation?' Intertax, 4.

Klein, Franz (2003): Abgabenordnung. München: Verlag C. H. Beck.
Knobbe-Keuk, Brigitte (1992): 'The EC corporate tax directives - anti-abuse provisions, direct effect, Germán implementation law'. Intertax, n. 8-9.

Martín Jiménez, Adolfo J.: (2002): 'Domestic Anti-Abuse Rules and Double Taxation Treaties: a Spanish Perspective', I y II. Bulletin. International Bureau of Fiscal Documentation, n. 11 and 12.

Masters, Colin (1994): is There a Need for General AntiAvoidance Legislation in the United Kingdom?' British Tax Review, no. 6.

Mcmahon Jr., Martin J. (2003): 'Beyond a GAAR: retrofitting the code to ?reind? in 21st Century Tax Shelters'. Tax Notes, March 17th, 2003 (1721 y ss.).

Meine, Hans-Gerd (1992): 'Steuervermeidung, Steuerumgehung, Steuerhinterziehung'. Wistra, 20. Heft 3, 20 March.

Murphy, Liam; NAGEL, Thomas (2002): The Myth of Ownership. Taxes and Justice. Oxford University Press.

OECD (1998): Harmful Tax Competition. An Emerging Global issue. [at: Van Raad, Kees (Ed.): Materials on International and EC Tax Law, vol. 1, 2002-03].

Pagone, G. T. (2001): 'Anti-avoidance Provisions and Tax Reform'. Australian Tax Review, vol. 30.

Palao Taboada, Carlos (1995): 'Economía y Derecho en la aplicación de las leyes tributarias'. Crónica Tributaria, n. 73

Palao Taboada, Carlos (1998): 'Existe el fraude a la ley tributaria?. Revista Estudios Financieros, n. 182.

Palao Taboada, Carlos (2003): 'La norma anti-elusión del proyecto de nueva ley general tributaria'. Revista Estudios Financieros, n. 66.

Passant, John (1997): 'Spotless Removing the stain of tax avoidance in Australia'. British Tax Review, n. 2

Pinto, Cario (2003): Tax Competition and EU Law, Kluwer, The Hague, 2003.

Rádler, Albcrt J. (1994): 'Do National Anti-Abuse Clauses Distort the Internal Market'. European Taxation, Vol. 34, no. 9.

Rádler, Albcrt J.; Laustcrer, Martin; Blumenberg, Jcns (1997): 'Tax abuse and EC law. Does the general application of the Germán Anti-Abuse Rule under section 42 of the Germán General Tax Act to Germán participations in lrish IFSC subsidiarles infringe community law?' EC Tax Review, n. 2.

Tipke, Klaus (1993): Die Steuerrechtsordnung. Kóln: Verlag Dr. Otto Schmidt. Tomo III.

Van Der Ende/Smit 2001, 'European Tax Law influences the new tax treaty', European Taxation, March 2001.

Vanderwolk, Jefferson (2002): 'Purposive Interpretation of Tax Statutes: Recent UK Decisions on Tax Avoidance Transactions'. 'Bulletin', International Bureau of Fiscal Documentation. February.

Vanistendael, Frans (2000): 'Legal framework for taxation'. THURONYI, Víctor (Ed.): Tax Law Design and Drafting. The Hague: Kluwer Law-IMF.

Vogel, Klaus (1977): 'Die Absichtung von Rechtsfolgen im Steuerrecht'. Steuer und Wirtschaft, n. 2.

Weber, Dennis (1996): 'A closer look at the general antiabuse clause in the Parent-Subsidiary Directive and the Merger Directive'. EC Tax Review, n. 2.

Weber, Dennis (1997): 'The first steps of the ECJ concerning an abuse-doctrine in the field of harmonized direct taxes'. F.C Tax Review, n. 1. 